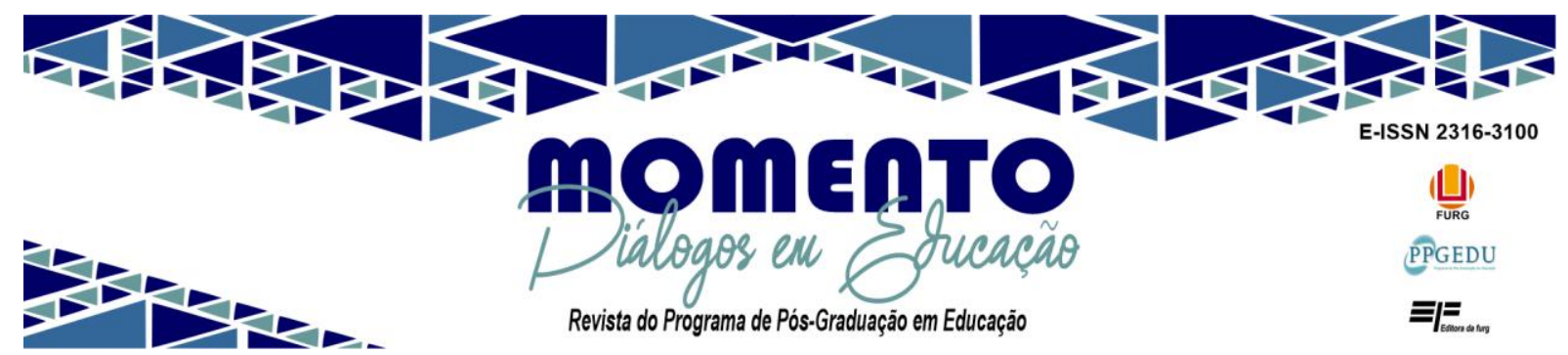

\title{
INTERAÇÃO ENTRE ALUNOS E PROFESSORES EM CURSOS TÉCNICOS A DISTÂNCIA
}

\author{
Rosimeire Aparecida Soares Borges* \\ Vânia dos Santos Mesquita** \\ Gilmar dos Santos Sousa Miranda***
}

\begin{abstract}
Resumo: Este estudo teve por objetivo investigar as concepções de professores em relação à interação entre professor e aluno, em cursos técnicos profissionalizantes, na modalidade Educação a Distância (EaD), ofertados por Institutos Federais de Educação em Minas Gerais. Fundamentada em pesquisadores como Valente (2015), Kenski (2015), Faria e Salvadori (2010), Lapa e Belloni (2012), dentre outros, de caráter exploratório e quanti-qualitativo, a pesquisa contou com a aplicação de dois questionários a trinta professores desses cursos. Os resultados mostram que, na concepção desses professores, existe a interação professor e aluno. No entanto, verifica-se a não utilização, por parte dos pesquisados, de ferramentas tecnológicas do Moodle, direcionadas a promover essa interação, e que o papel do docente nesses cursos $\mathrm{EaD}$, muitas vezes, é desempenhado pelo tutor, o que indica ser essa interação ainda incipiente. Ações dos professores desses cursos técnicos $\mathrm{EaD}$, no sentido de promover a interação professor e aluno, pode contribuir para uma educação de qualidade, frente aos avanços tecnológicos e uma formação mais humana do aluno.
\end{abstract}

Palavras-chave: Ambientes virtuais de aprendizagem. Educação a distância. Interação professor aluno.

\section{INTERACTION BETWEEN STUDENTS AND TEACHERS IN DISTANCE TECHNICAL COURSES}

\begin{abstract}
The purpose of this study was to investigate how faculty interpret the interaction between teachers and students in professional technical courses, in the form of Distance Education (in Portuguese, EaD) offered by Federal Institutes of Education in Minas Gerais. Based on researchers such as Valente (2015), Kenski (2015), Faria and Salvadori (2010), Lapa
\end{abstract}

\footnotetext{
Pós-Doutorado pelo Programa de Pós-Graduação em Educação Matemática na Universidade Anhanguera de São Paulo, em 2017, sob a supervisão do Professor Dr. Ubiratan D Ambrosio. Doutorado em Educação Matemática pela Universidade Bandeirante de São Paulo (2011), tendo realizado o Estágio de doutoramento na Escola Superior de Educação de Lisboa/Portugal em 2007. Mestrado em Educação Matemática pela Pontifícia Universidade Católica de São Paulo (2005). Possui graduação em Matemática pela Universidade do Vale do Sapucaí (2002). Atualmente é professora da graduação e do Mestrado em Educação da Universidade do Vale do Sapucaí -UNIVÁS, Pouso Alegre/MG.

** Possui mestrado em Educação pela Universidade Estadual de Campinas (2000) e doutorado em Comunicação e Semiótica pela Pontifícia Universidade Católica de São Paulo (2013). É graduada em Pedagogia (1984) e em Comunicação Social-Jornalismo (1992), pela Faculdade de Filosofia, Ciências e Letras Eugênio Pacelli, da Universidade o Sapucaí (Univás).

*** Mestre em Educação pela UNIVÁS (2015). Graduado em INFORMATICA com ênfase em GESTÃO DE NEGÓCIOS pela FATEC SP (2008) e com Licenciatura Plena em FISICA pela UNIFEG (1997). Especialista em EDUCAÇÃO À DISTÂNCIA. Atualmente é Analista de Tecnologia da Informação no IFSULDEMINAS. Atuou como Professor-tutor do IFTM, da UNIFESP, do IFSULDEMINAS, Professor Mediador da UNIVAS, Tutor do IFSULDEMINAS, Diretor Substituto de TI, Coordenador de Sistemas e Coordenador de Operações de TI do IFSULDEMINAS. Atuou também como Coordenador de Tutoria do Programa Profuncionário e Professor Formador EAD do IFSULDEMINAS.
} 


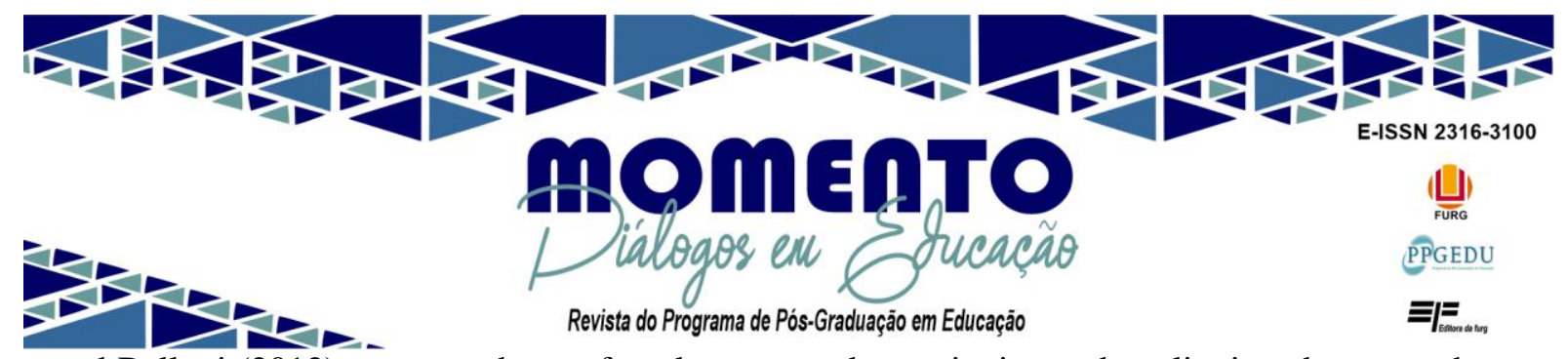

and Belloni (2012), among others, of exploratory and quantitative and qualitative character, the research analysed the results of two questionnaires given to thirty teachers of these courses. The responses show that, in their conception, there is interaction between teachers and students. However, we verify that the respondents do not use Moodle technology tools that are aimed to promote such interaction, and that the teachers' role in those $\mathrm{EaD}$ courses is often performed by the tutor, indicating that the interaction is still incipient. Actions taken by the teachers of the $\mathrm{EaD}$ technical courses aimed at promoting interaction between teachers and students can contribute to a quality education in face of the technological advances, and a more humanized students' education.

Keywords: Virtual learning environments. Distance education. Student teacher interaction.

\section{INTRODUÇÃO}

As Tecnologias Digitais da Informação e Comunicação (TDIC) têm provocado inúmeras transformações, em diversas áreas, especificamente na área da educação. Assim, a ampla ascensão da internet disseminou diferenciadas ferramentas, que podem ser utilizadas no processo de ensino e aprendizagem nas aulas. Os conceitos de tempo e de espaço sofreram um deslocamento e passaram a ser compreendidos sob uma nova lógica. Desse modo, a informação pode ser obtida pelos envolvidos no processo educacional, de diferentes formas e em diferentes lugares. Nesse contexto, destaca-se a expansão da Educação a Distância (EaD).

No Brasil, a EaD tem oferecido vários cursos nos níveis médio, superior e pósgraduação, que, com o advento da internet, tiveram um crescimento expressivo de procura. São subsidiados pelos Ambientes Virtuais de Aprendizagem (AVA) e chegam às mais longínquas localidades. Esses ambientes são sistemas computacionais disponíveis na Web, que integram múltiplas mídias, linguagens e recursos na mediação da EaD. Para Nascimento e Silva (2018, p. 85),

No contexto da EaD, o AVA tornou-se uma ferramenta quase dominante no que diz respeito aos recursos utilizados com fins a essa modalidade de ensino, podendo ser designado como um espaço virtual micro pertencente ao ciberespaço e utilizado como ferramenta no processo ensino e aprendizado. Sua estrutura consiste na utilização de novas metodologias desenvolvidas a partir do agrupamento combinado de mídias e que são escolhidas de acordo com a necessidade da instituição, do público envolvido e da abrangência do curso. 


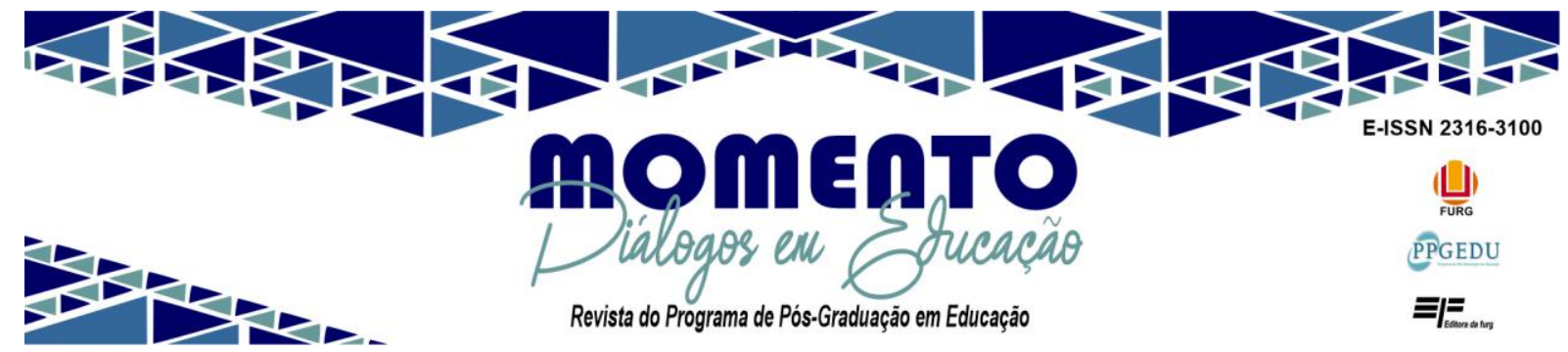

Nos AVA, as atividades da EaD se desenvolvem no espaço em que o aluno se localiza, e ainda no tempo e ritmo do aluno, de acordo com a sua disponibilidade. Nesses ambientes, o professor utiliza recursos digitais de aprendizagem, tais como: fórum, e-mail, conferência, banco de imagens, recursos, hipertextos, vídeos, textos, dentre outros. (PRADO; VALENTE, 2002). Desse modo, é necessário um aprendizado específico por parte dos docentes, e o aluno precisa estar amparado e seguro, para que consiga interagir e participar da construção do próprio conhecimento.

Trata-se, portanto, da parte mais visível de todos os recursos tecnológicos que dão suporte à EAD, e é por meio do AVA que os conteúdos dos cursos são disponibilizados e que ocorrem as interações entre os atores envolvidos no processo educativo. (GARCIA COELHO; TEDESCO, 2017). Além disso, permitem uma comunicação síncrona e assíncrona entre os professores e alunos. Segundo Valente, (2015, Prefácio) “[...] a interação do aluno com o professor são aspectos fundamentais do processo de ensino e de aprendizagem que a sala de aula tradicional não incentiva.”.

A qualidade do processo educativo, na EaD, está relacionada a uma combinação de fatores e atores, como a infraestrutura, as ferramentas e os recursos tecnológicos empregados nos AVA, os materiais veiculados, a proposta pedagógica, o envolvimento do aluno e a qualificação dos professores, tutores, técnicos e monitores. Desse modo, atualizar as metodologias de ensino e utilizar recursos e ferramentas digitais que auxiliem na melhoria da qualidade do ensino para os alunos são ações esperadas do professor, considerado o responsável pela mediação da aprendizagem, em diferentes momentos e ambientes. Sendo assim, a sala de aula deixou de ser o único ambiente em que pode ocorrer a aprendizagem. (PRADO; VALENTE, 2002).

O impacto que as novas tecnologias causaram na educação exige uma reflexão sobre as formas de ensinar e aprender. Ao docente, cabe fazer escolhas das ferramentas e recursos tecnológicos que irá utilizar em suas aulas, de forma adequada ao público de alunos e aos objetivos a alcançar. Nesse cenário, as TDIC, como possibilidades didáticas, exigem do professor a qualificação profissional e um redirecionamento da prática docente, baseada em novas aprendizagens. (KENSKI, 2015).

Este estudo enfoca os cursos técnicos em $\mathrm{EaD}$, nível médio, por apresentarem 


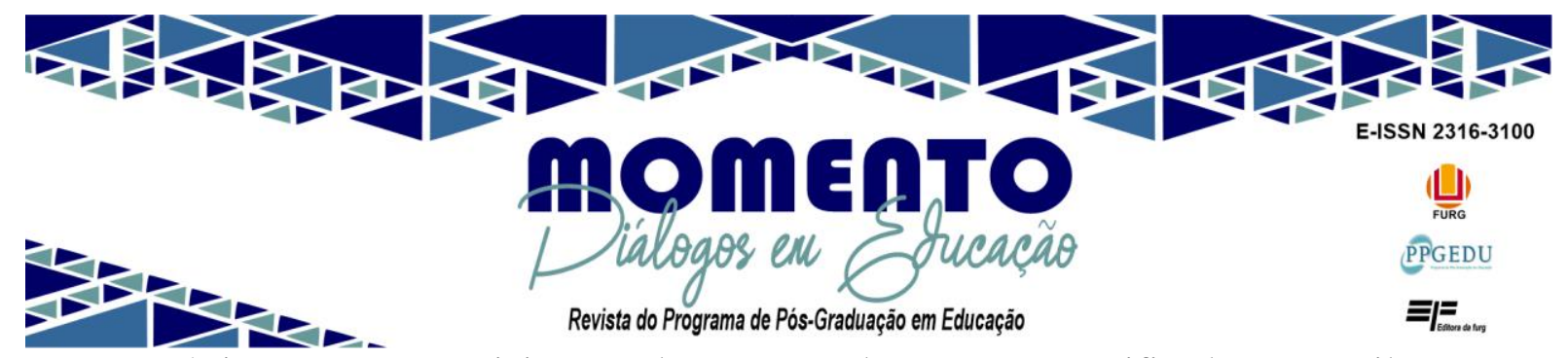

características novas e participarem do processo de expansão, verificado no Brasil, com a implantação do Programa Governamental Rede e-Tec. De acordo com o MEC, os Institutos Federais de Educação são considerados referência na modalidade de ensino técnico, permitindo qualificar profissionais para os mais amplos setores econômicos do país, além de promover a pesquisa e desenvolver produtos e serviços novos, colaborando com o setor produtivo brasileiro. (BRASIL, 2015).

Como local para este estudo, escolheu-se um Instituto Federal de Educação de Minas Gerais, que atende, no âmbito da EaD, um número aproximado de 6.000 alunos, distribuídos nos seguintes cursos técnicos oferecidos: Técnico em Alimentos, Técnico em Cafeicultura, Técnico em Informática, Técnico em Meio Ambiente, Técnico em Vigilância em Saúde e Técnico em Análises Clínicas, que contam com polos de apoio presencial em várias cidades do estado.

Considerando esse cenário colocado pelas TDIC na EaD e o lócus selecionado para este estudo, duas questões norteadoras emergiram: quais são os recursos e ferramentas utilizados, no AVA, pelos docentes de cursos técnicos $\mathrm{EaD}$ nesses Institutos? E, ainda: na concepção dos professores que atuam nesses cursos, existe interação entre docente e aluno, nos processos de ensino e de aprendizagem no AVA?

O AVA utilizado por esse Instituto é o Moodle, destinado a subsidiar a aprendizagem em um ambiente virtual. De acordo com Sabbatini (2007, p. 1), o Moodle é um "sistema de gestão do ensino-aprendizagem, com muitos recursos disponíveis e de alta qualidade". Trata-se de um sistema com codificação aberta, o que permite aos programadores efetuarem modificações ou alterações em sua modelagem, de acordo com a filosofia da General Public License, de software livre.

Considerando esses pressupostos, este estudo teve por objetivo conhecer os recursos, ferramentas e metodologias utilizados por docentes, no AVA utilizado nos cursos técnicos EaD em Institutos Federais de Educação de Minas Gerais. Pretendeu-se, ainda, investigar as concepções desses professores, em relação à interação entre professor e aluno nesses ambientes.

A relevância deste estudo está na contribuição para reflexões acerca da $\mathrm{EaD}$, que, embora tenha na base de sua constituição a preocupação com o acesso à educação daqueles que não têm oportunidade de frequentar a escola, em tempo e espaço 


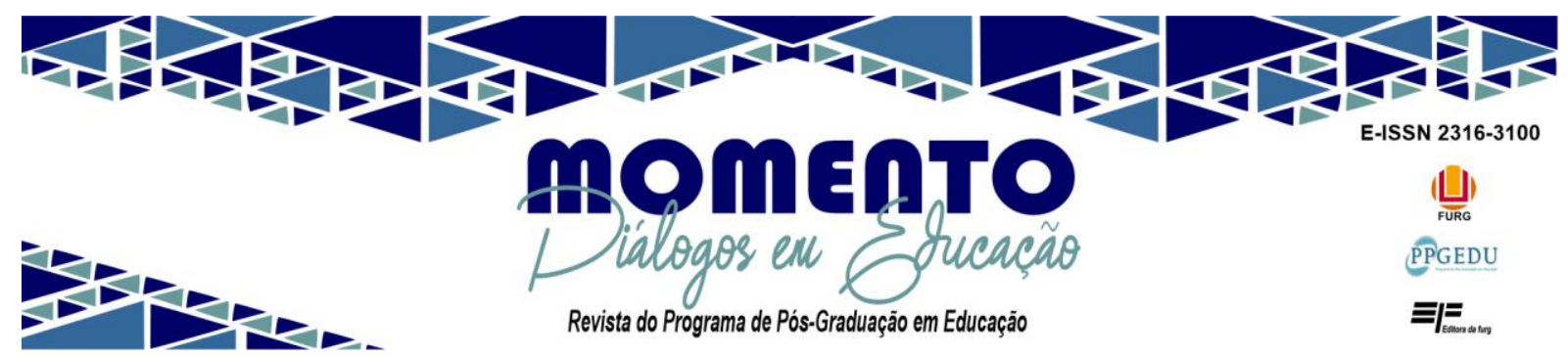

considerados ideais (FARIA; SALVADORI, 2010), está aberta a todos os públicos que desejam estudar a distância. $\mathrm{A} \mathrm{EaD}$ vem atendendo às necessidades de, cada vez mais pessoas que anseiam por estudar e, por motivos vários, optam por essa modalidade de ensino.

\section{FUNDAMENTAÇÃO TEÓRICA}

As concepções dos professores têm um significativo aspecto de sociedade, do coletivo em que o ser humano se insere e são as interações que ocorrem entre os indivíduos que geram essas concepções. Dessa forma, esse conjunto de elementos sociais, empregados na construção do saber, confirma uma relação de interação entre as práticas e as concepções desses grupos. As práticas influenciam as concepções, e vice-versa. (GARNICA, 2008). O termo concepção foi admitido não apenas como determinante das ações dos professores, mas como a relação entre suas concepções e práticas, de modo que se inter-relacionam e se retroalimentam. (GARNICA; FERNANDES, 2002).

Em relação à interação entre os atores do processo educativo nos ambientes virtuais de aprendizagem, tratando-se de ensino a distância, é uma das abordagens com proposta de construção colaborativa do conhecimento, conforme evidenciam Garcia Coelho e Tedesco (2017). No âmbito da EaD, a interação, segundo Borokhovski et al. (2012), é entendida como uma troca de forma ativa de diversas ações e informações entre os atores do processo educativo. Segundo Onrubia, Colomina e Engel (2010), a interação é essencial para a aprendizagem colaborativa, que é um processo em que há o compartilhamento, negociação e construção de significados, de forma conjunta, para a solução de um problema, criação ou produção de algo por parte dos participantes.

No entanto, de acordo com Garcia Coelho e Tedesco (2017), manter a interação no AVA torna-se um desafio mais amplo do que em contextos de educação presencial, essencialmente por questões de tempo e espaço, com o uso de tecnologias. Para que haja a aprendizagem colaborativa, a educação a distância precisa estimular a curiosidade intelectual dos alunos, de maneira a envolvê-los em atividades de ensino que sejam produtivas e que venham a influenciar a aprendizagem. Esses autores ainda 


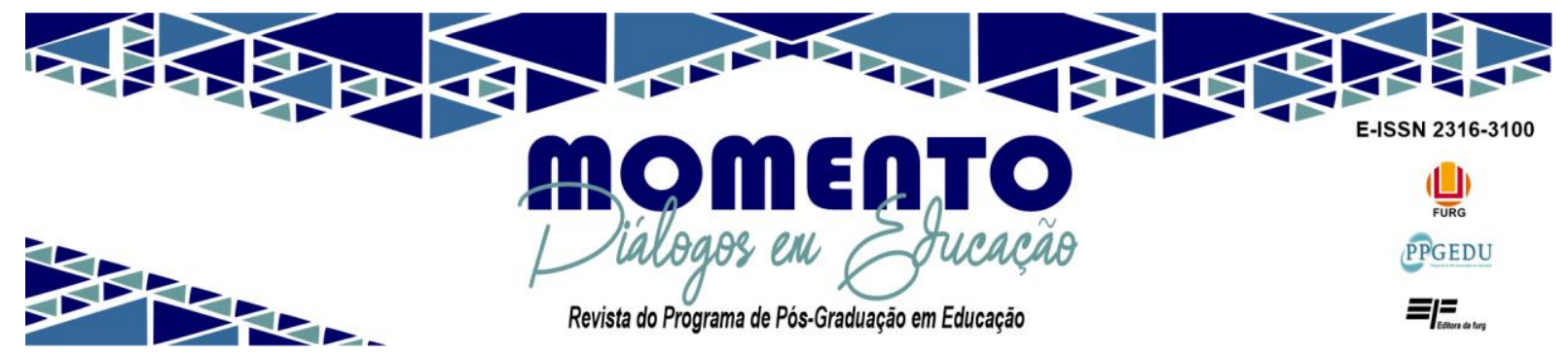

defendem que, para que haja interação entre os envolvidos na educação EaD no AVA, deveriam ser consideradas ações de argumentar pontos de vista, responder, agregar novas ideias, negociar e de oferecer novas perspectivas a discussões de problemas reais, o que torna o papel dos envolvidos nessa modalidade de educação de suma importância, essencialmente o dos professores.

Kenski (2003, p. 90) refere-se ao papel do professor como “[...] um incansável pesquisador. Um profissional que se reinventa a cada dia, que aceita os desafios e a imprevisibilidade da época para se aprimorar cada vez mais”. Nessa direção, Garcia et al. (2011) afirmam ser possível a expansão do repertório tecnológico dos professores, uma forma de instrumentalizá-los para a prática pedagógica. São aspectos que mostram a necessidade de uma constante formação dos docentes, para que possam inovar sempre com práticas exitosas em suas aulas.

Além disso, a formação continuada dos docentes pode auxiliá-los a serem atuantes críticos, reflexivos e competentes no uso das tecnologias digitais, o que vai além da questão técnica de infraestrutura da instituição de ensino para o uso das tecnologias. Esses avanços repercutiram na mudança do papel do professor no trabalho pedagógico: antes detentor e propagador do conhecimento, tendo como essencial incumbência o de instruir, incentivar e orientar o aluno. Entretanto, devido às concepções, já sedimentadas pelos docentes, ainda se percebe uma reação negativa de muitos professores, diante das inovações e mesmo uma resistência em relação a esses usos, embora as TDIC, na educação, possam auxiliar no processo de ensino e de aprendizagem dos conceitos pelos alunos.

O trabalho do professor em sala de aula é determinado por suas concepções, que direcionam suas práticas pedagógicas e seu modo de ensinar. Para Ferreira e Ventura (2007, p. 113), as concepções consistem em "uma forma de conhecimento fortemente influenciada pelas emoções, crenças e valores”. Concepção consiste em um processo de construção mental do mundo real, que ocorre com base em informações que o indivíduo adquire, por meio dos seus sentidos ou dos relacionamentos com outras pessoas ou grupos no decorrer de sua vida, a partir da ação cultural e social, influenciado pelas mídias, atividades sociais e profissionais. Assim, as ações dos professores estão relacionadas, diretamente, às suas concepções, afirma Ponte (1992). 


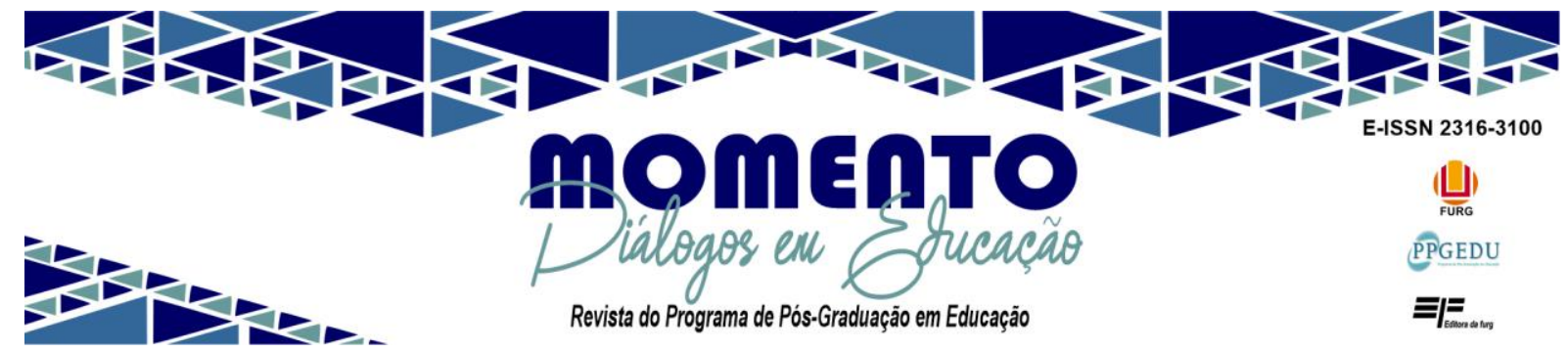

Nessa direção, este estudo abordou a modalidade de ensino EaD em que, da interação do professor com o aluno nos AVA, não como único detentor do saber e responsável pela transmissão do conhecimento, possam decorrer outros comportamentos, como o incentivo ao aluno e sua participação, de modo a auxiliar na construção do conhecimento e no desenvolvimento de sua autonomia. Dessa forma, entende-se que, com alunos cada vez mais familiarizados com os meios digitais, a ação do professor, no preparo de aulas para os ambientes virtuais de aprendizagem, é um desafio constante, pois a formação deve ser concebida para que os estudantes sejam críticos e reflexivos, nesta sociedade da informação.

Esse novo cenário de ascensão das TDIC traz impactos para os processos educativos e para a formação dos professores, pois essas tecnologias podem permitir aos estudantes o acesso a uma gama de informações de forma rápida. Vem, ainda, desafiar os professores, exigindo-lhes um aperfeiçoamento constante dos métodos de ensino utilizados, em uma atuação como orientadores, incentivadores e motivadores no processo de formação do aluno, que passa a ser muito mais crítico, frente ao oceano de informações virtuais a que tem acesso. (GARCIA et al., 2011).

Essas mudanças exigem que as escolas se tornem ambientes interdisciplinares, em que ocorra o uso pedagógico das TDIC, de forma consciente e funcional. Braga e Vóvio (2015) avaliam que o currículo não pode estar engessado, não pode mais ser tradicional - currículo, aqui, referido como o projeto político pedagógico dos cursos técnicos em EaD, nos institutos pesquisados. Para Almeida et al. (2017), a disseminação do uso dessas tecnologias, em decorrência do avanço da ciência e transformações educacionais e sociais, leva o referencial sobre currículo a adotar novas características, abordando uma multiplicidade de orientações teóricas e metodológicas.

De uma forma lógica, sendo o professor o ator principal do processo educativo, seus saberes e concepções afetam a formação de seus alunos. Desse modo, é relevante perceber a importância de se conscientizar em relação às próprias concepções. (FREIRE, 2014). As escolhas do professor são dependentes de suas concepções e sua identidade também se constrói, de acordo com as influências culturais e sociais do ambiente em que se insere, englobando sua formação, vivência e vida financeira. 


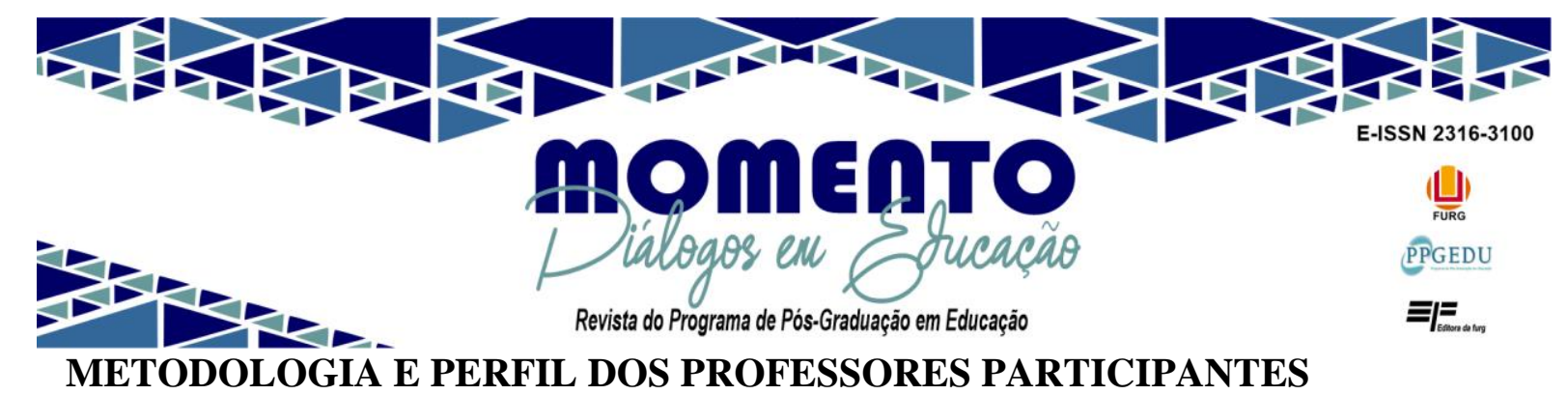

Este estudo, com abordagem quanti-qualitativa e perspectiva exploratória, envolveu 30 professores dos cursos técnicos $\mathrm{EaD}$, de um Instituto Federal de Educação de Minas Gerais. Para conhecer as concepções dos professores participantes deste estudo e seu perfil de formação, dois questionários com questões fechadas foram utilizados como instrumentos para a coleta de dados, quais sejam: "Concepções dos professores acerca da relação metodologias de ensino e interação nos AVA" e "Perfil dos Professores dos Cursos Técnicos EaD da Instituição", aplicados virtualmente pelo Google Forms. As análises dos dados coletados com esses questionários foram realizadas qualitativamente, à luz dos teóricos que fundamentam este estudo e com auxílio de aspectos quantitativos.

A identidade do professor está relacionada ao seu modo de ser e de estar no mundo, interferindo em suas perspectivas, em relação à sua formação e às suas formas de atuação. Essa identidade decorre das interações sociais complexas na sociedade. De acordo com Nóvoa (2013), a identidade consiste em um lugar de lutas e conflitos, em um espaço de construção dos modos de ser e de estar na docência, em uma mistura dinâmica, que caracteriza o modo como cada um se identifica como docente.

No que tange ao perfil desses professores participantes, têm média de idade de 36 anos, são em maioria (56\%) do sexo masculino, servidores públicos efetivos, há 4 quatro anos, pelo menos, no magistério na $\mathrm{EaD}$, nesse Instituto, e com carga horária semanal de 40 (quarenta horas). Sobre a formação acadêmica dos professores pesquisados, também foco deste estudo, observou-se que, em relação à primeira graduação, 52\% fizeram bacharelado, e 32\% cursaram Licenciatura, e $16 \%$ dos docentes pesquisados fizeram cursos tecnológicos. Com referência à pós-graduação, quase a totalidade (96\%) possui pós-graduação Lato Sensu ou Stricto Sensu. Mais especificamente, $50 \%$ dos pesquisados concluíram mestrado ou doutorado ou ainda pós-doutorado, sendo que 40\% fizeram especialização, 32\% concluíram Mestrado, 20\% Doutorado e 4\% Pós-doutorado.

Em toda a história da Educação, houve um questionamento sobre a formação dos professores, no que tange à ampliação do universo cultural e científico, em 


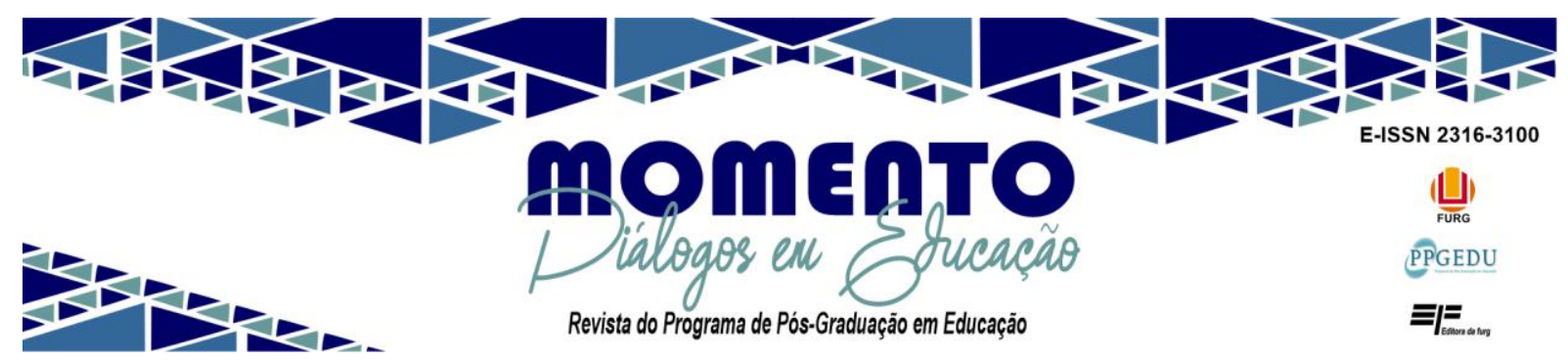

consonância com às necessidades e exigências culturais e tecnológicas vigentes. Em relação ao uso das TDIC, na EaD, os professores têm enfrentado grandes desafios. Entretanto, os cursos de formação inicial e continuada nem sempre preparam os professores para esses usos. (PLACCO; SILVA, 2000). Corroborando, dos professores pesquisados, $52 \%$ não tiveram componente curricular que os preparasse para uso das TDIC, na prática pedagógica, no decorrer do curso superior e/ou de pós-graduação. No que tange à presença de componentes curriculares que auxiliassem na formação dos professores investigados para atuar na $\mathrm{EaD}, 64 \%$ dos professores responderam que "Não" tiveram, o que vem abonar o que Gatti (2000) afirmou, que o educador geralmente não possui a formação apropriada para atuar nesta modalidade de ensino, como também não recebe a atenção necessária nos cursos de formação de professores. A ausência de uma formação adequada dos docentes para a atuação também é citada por Kenski (2015) para quem, de modo geral, o professor muitas vezes não está preparado para atuar.

A formação do professor implica em um constante comprometimento para realizar reflexões sobre a própria prática e atualização constante dos conhecimentos. É necessário que cursos de formação de professores auxiliem-nos a combinar sua didática com as exigências da sociedade, de modo que o aluno consiga estabelecer articulações dos conceitos ministrados nas aulas, as mídias e multimídias disponíveis (KENSKI, 2015). Os professores pesquisados mostraram possuir interesse pela formação continuada frente a demanda depositada nas formas de se organizar e conviver socialmente. Entretanto, diante do grande impacto do uso das TDIC, os cursos pelos quais esses professores passaram não ofereceram fundamento necessário para o uso dessas tecnologias na Educação e na EaD.

A necessidade de adequação da formação dos professores para o uso das TDIC mencionada por Lapa e Belloni (2012) ainda se faz presente, visto que há muitos docentes atuando na $\mathrm{EaD}$ e fazendo uso das TDIC sem estar preparados adequadamente, o que é prejudicial aos alunos, professores e a educação como um todo. Para esse autor, a EaD e as TDIC permitem abranger grande espaço territorial, e para tanto, um docente preparado para atuar na $\mathrm{EaD}$ terá que dominar também as 


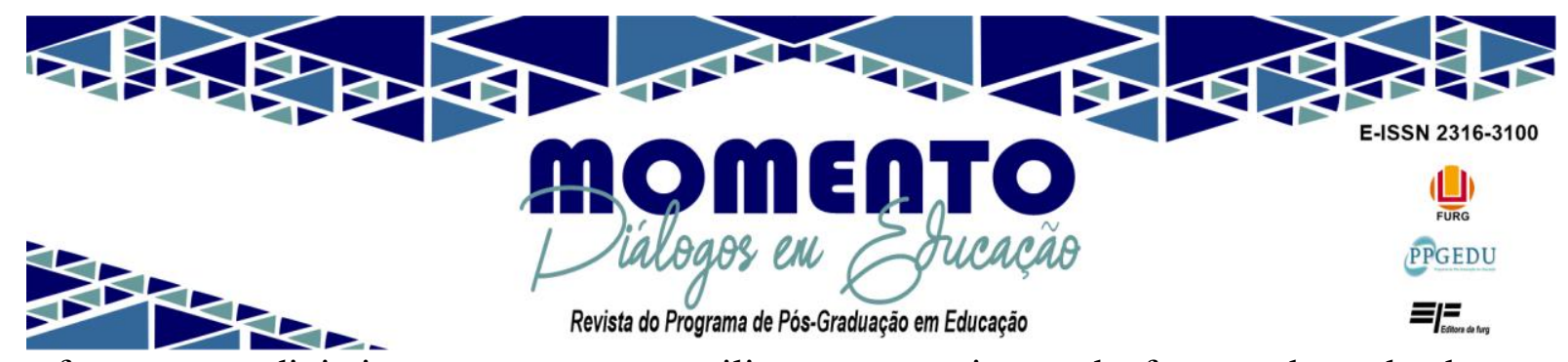

ferramentas digitais para que possa utilizar e apropriar-se de forma adequada dos recursos tecnológicos em suas aulas.

\section{RESULTADOS E DISCUSSÃO}

Com base nas informações constantes nas respostas dos professores pesquisados ao questionário "Concepções dos professores acerca da relação metodologias de ensino e interação nos AVA", apresentamos aqui os resultados e a discussão, momento em que se faz o entrecruzamento dos dados obtidos nesta pesquisa. Vale salientar que, como alguns dos professores participantes deste estudo têm tanto o bacharelado quanto a licenciatura, sendo servidores públicos efetivos e que lidam com as tecnologias constantemente há pelo menos quatro (4) anos no magistério na EaD nesse Instituto, optou-se por não diferenciar as concepções dos professores pesquisados em relação à formação, apresentando-as como "concepções dos docentes" ou “ concepções dos professores".

Como já mencionado, o professor é considerado o ator principal do processo formativo e os saberes e concepções docentes têm influência direta na formação de seus alunos. (FREIRE, 2014). Segundo Kenski (2015), pode-se dizer que os novos conceitos de educação mediada pelas TDIC exigem reaprendizagens e atualizações do conhecimento docente. Uma formação continuada pode ser oferecida pela própria instituição de ensino em que atuam os docentes ou por outros seguimentos externos ao sistema educacional.

Em relação ao nível de exigência do curso técnico em que atuam, 56\% dos professores pesquisados consideraram adequado e 44\%, razoavelmente adequado. Já sobre o grau de conhecimento que possuem acerca das ferramentas e recursos tecnológicos integrados nos cursos técnicos $\mathrm{EaD}$ e suas funcionalidades e utilização, os resultados mostram que: apenas $24 \%$ dos professores pesquisados responderam "Excelente", 36\% "Muito Bom" (Gráfico 01), o que reflete que nem todos se consideram bem preparados para usufruir desses recursos. 


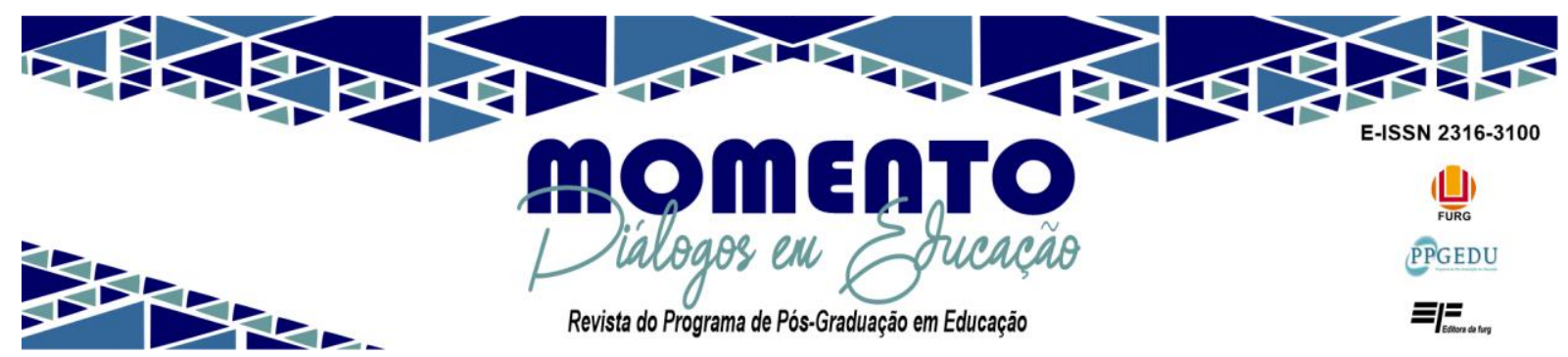

GRÁFICO 1 - Conhecimento dos docentes em relação às TDIC utilizadas

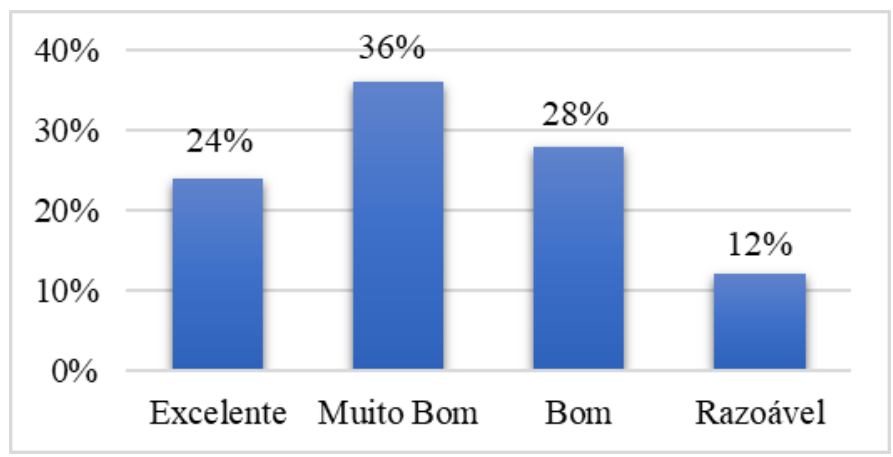

Fonte: Elaborado pelos autores

Esse resultado vem refletir o que discutem Soares-Leite e Nascimento-Ribeiro (2012), para quem um dos entraves em relação à utilização das TDIC na educação brasileira é que grande parte dos professores não possuem conhecimento e domínio sobre essas tecnologias, por terem tido uma formação acadêmica deficiente, quanto ao seu uso, o que precisa ser modificado. Conforme já apontado, para se obter bons resultados no processo de ensino e aprendizagem na $\mathrm{EaD}$, o professor deve ter conhecimento das ferramentas tecnológicas utilizadas e do projeto pedagógico do curso, de modo que possa ser um agente mediador e motivador nesse processo.

Perguntou-se aos professores participantes se consideram que o Projeto Pedagógico dos Cursos (PPC) do curso técnico EaD, em que atuam, contém aspectos das TDIC, e os resultados mostraram que: $28 \%$ acreditam que estes aspectos existem e se encontram presentes nos procedimentos de ensino e de avaliação; 22\%, nos conteúdos; 21\%, nos objetivos; 18\%, nas ementas, e 11\%, nas bibliografias (Gráfico 2).

Desse modo, o que se pode notar é que o PPC desses cursos técnicos, de alguma forma, contempla as TDIC, mas não dá para se ter uma noção da abrangência. O que se pode afirmar é que, conforme Braga e Vóvio (2015), o currículo não pode estar engessado e deve permitir, segundo Almeida et al. (2017), a inserção de aspectos que visem a uma multiplicidade de orientações teóricas e metodológicas. 


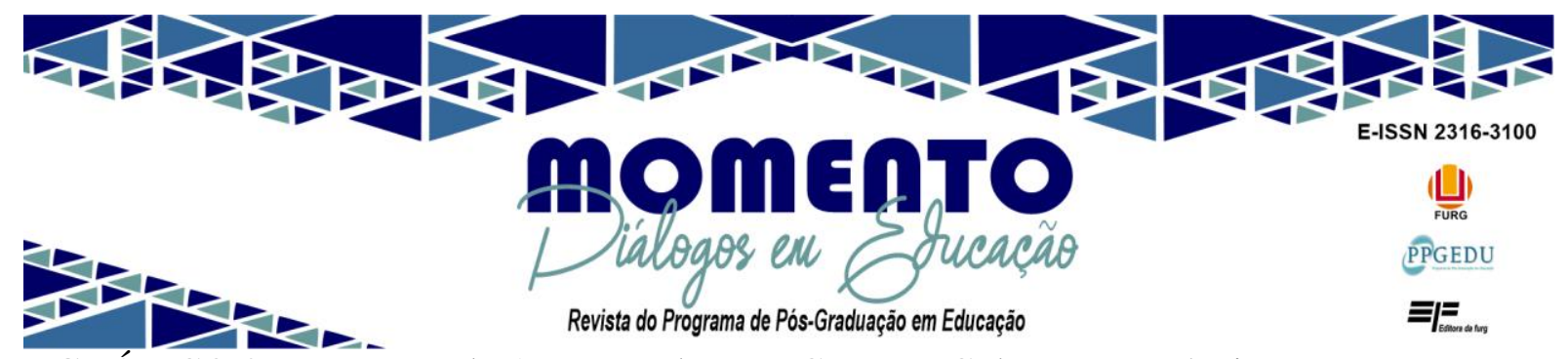

GRÁFICO 2 - Presença de Aspectos das TDIC nos PPC dos cursos técnicos

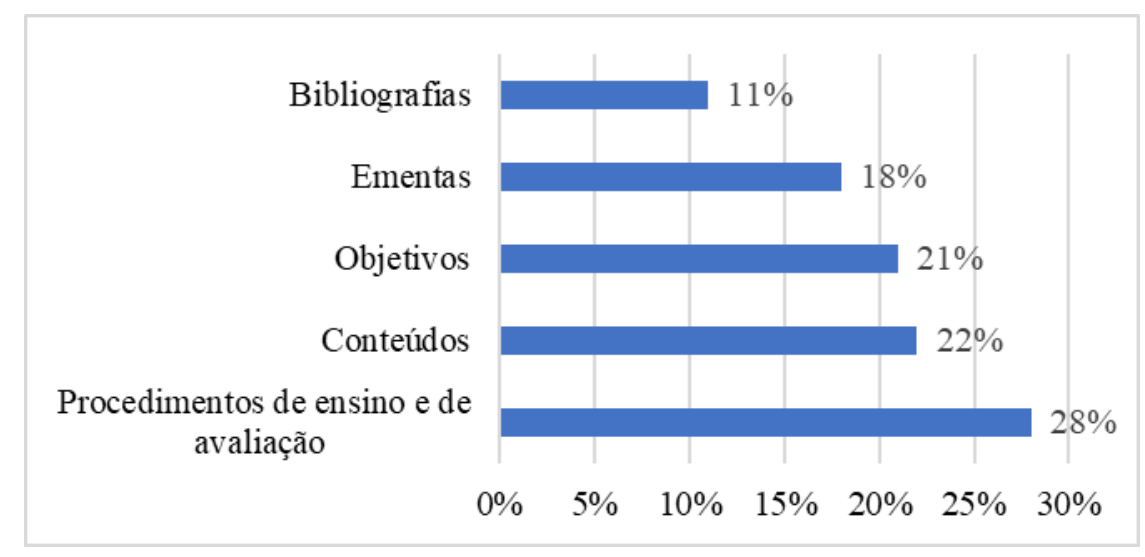

Fonte: Elaborado pelos autores

Os objetivos do curso e as possibilidades metodológicas presentes no PPC foram, também, referenciados no questionário, e a maioria (72\%) dos professores pesquisados considerou "adequados" e o restante (28\%) admitiu serem parcialmente adequados ou inadequados. De acordo com Nascimento e Silva (2018), perceber as possibilidades de metodologias que possam provocar mudanças no âmbito escolar pode provocar transformações na educação.

Quanto aos tipos de instrumentos de avaliação que adotam predominantemente no Moodle, 28\% respondeu utilizar testes on-line com correção automática, 28\% exercícios postados em texto, $21 \%$ fóruns, $13 \%$ testes online e $10 \%$ pesquisas. (Gráfico 3).

GRÁFICO 3 - Tipos de instrumentos de avaliação utilizados no Moodle

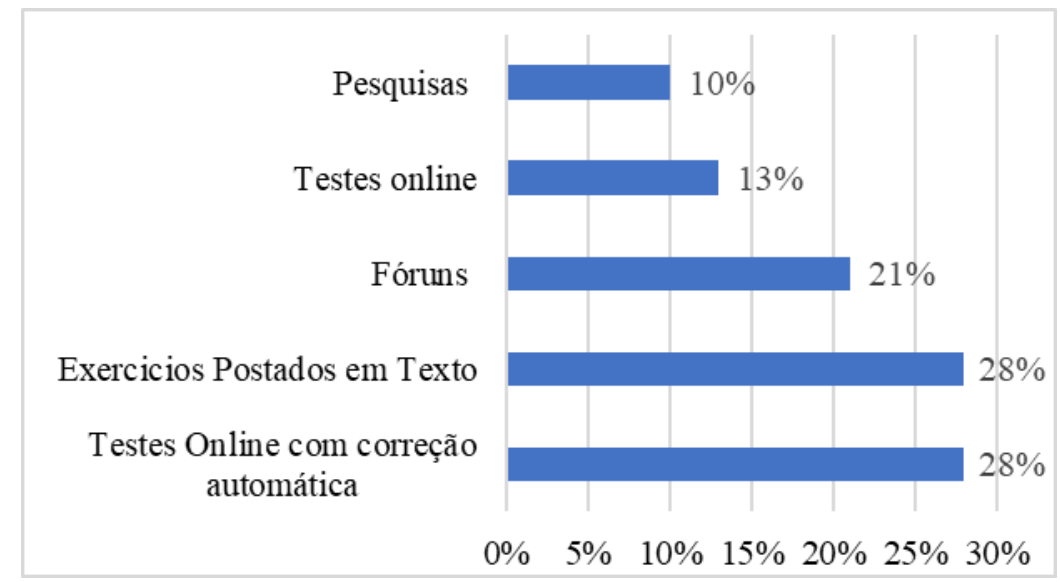

Fonte: Elaborado pelos autores 


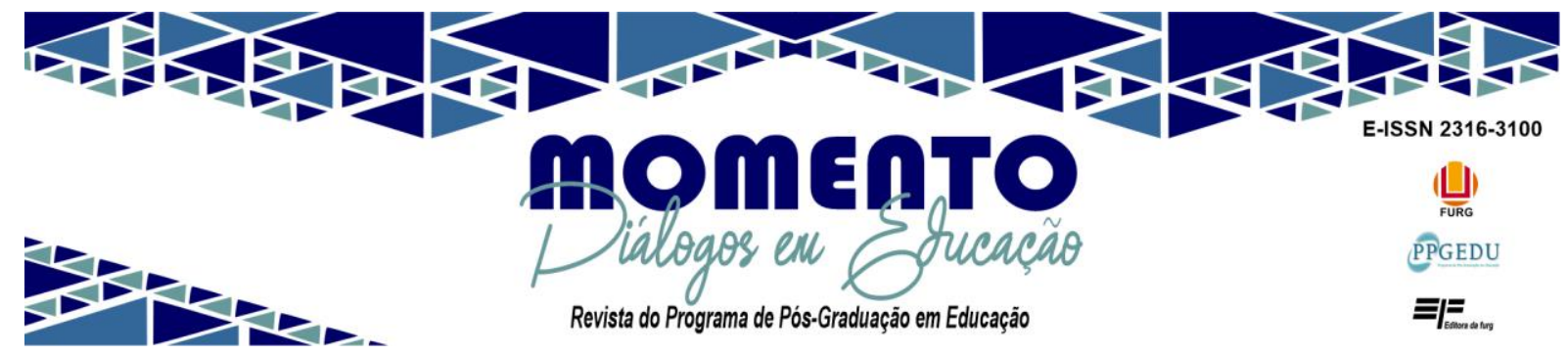

O Moodle, segundo Souza e Burnham (2008), possui uma variedade de ferramentas capazes de oferecer aos usuários diversas informações e formas de comunicação com os alunos e de avaliação do aprendizado, podendo ser úteis nos processos de ensino e de aprendizagem. No entanto, ao observar que $79 \%$ dos docentes responderam utilizar testes, exercícios em forma de texto e pesquisas que realizam, individualmente, metodologias que replicam práticas realizadas no ensino presencial, nota-se que não se valem do princípio da interatividade, que caracteriza os AVA, não estão considerando a possibilidade de construção compartilhada do conhecimento que necessita da interação dos alunos e, portanto, não exploram o potencial pedagógico dos AVA na proposição de avaliações. Isto vem contrariar a promoção de espaços de interação virtual, que pode facilitar a aprendizagem colaborativa dos alunos, conforme destacam Garcia Coelho e Tedesco (2017). Isto porque, ao utilizarem apenas ferramentas que possibilitam a comunicação assíncrona, com base somente em textos, acabam por prejudicar a interação. Esse tipo de comunicação dificulta o diálogo aberto, o que poderia fundamentar a troca de ideias de forma crítica e construtiva.

\subsection{Os professores e os ambientes virtuais de aprendizagem}

Ambientes virtuais de aprendizagem, como o Moodle, são necessários para a Educação a Distância, porém exigem conhecimentos específicos dos professores. Em relação ao nível de conhecimento que possuem sobre esse ambiente, $24 \%$ afirmaram que é “excelente”, 40\% “Muito Bom”, 32\% “Bom” e 4\% "Razoável” (Gráfico 4).

GRÁFICO 4 - Conhecimento dos docentes pesquisados sobre o Moodle

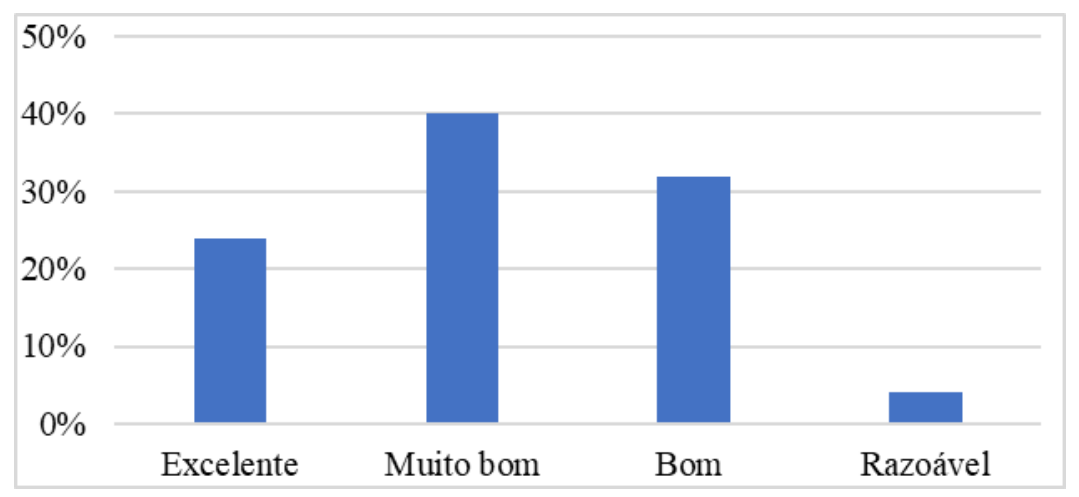

Fonte: Elaborado pelos autores 


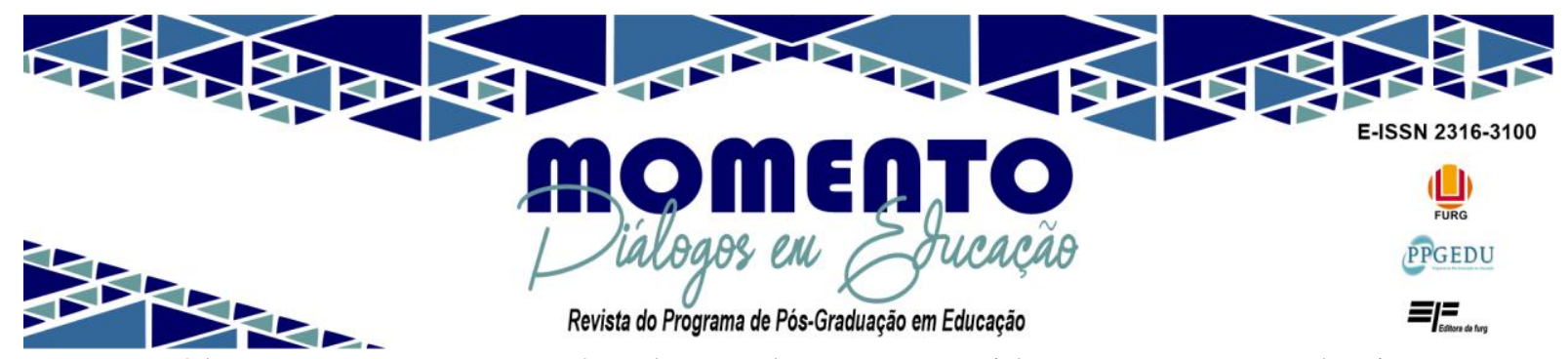

Observa-se que apenas $4 \%$ desses docentes consideraram que o conhecimento que possuem sobre o Moodle, que utilizam nas aulas é razoável, enquanto os demais apontaram possuir de bom a excelente conhecimento, sobre esse ambiente. Para Kenski (2015), exige-se a atualização permanente dos conhecimentos dos professores pela velocidade das mudanças do mundo informatizado. Assim, aprender sempre se torna um fato natural e perceptível para essa atualização.

Sobre os recursos do Moodle que são utilizados pelos docentes participantes desta pesquisa para a postagem das atividades, o que se evidencia é o fórum de discussão (48\%), seguido das postagens de documentos .pdf, .doc, etc. (28\%), postagens de vídeos (20\%) e 4\% usam dois recursos: postagens de documentos e fóruns (Gráfico 5).

GRÁFICO 5 - Recursos tecnológicos utilizados pelos docentes no Moodle

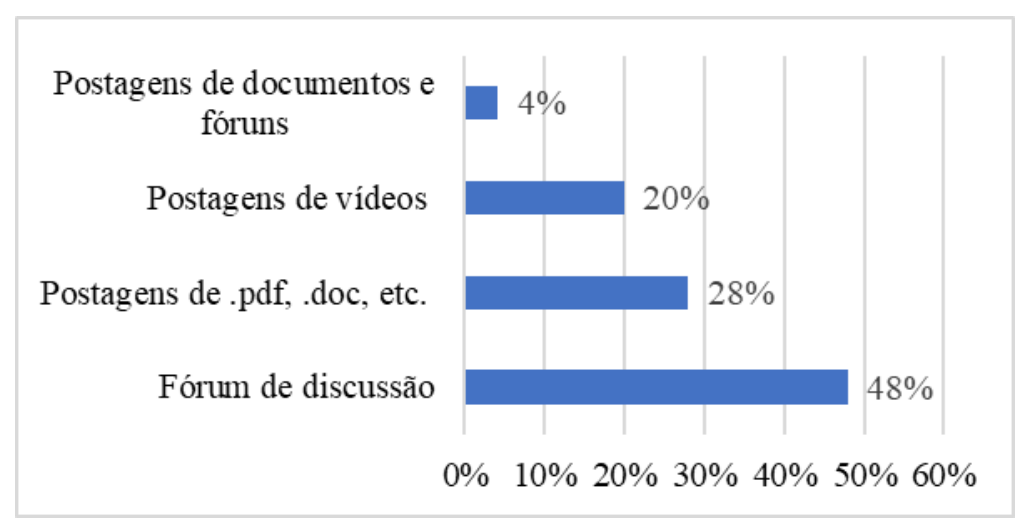

Fonte: Elaborado pelos autores

Essa prevalência na utilização do fórum de discussão poderia ser justificada pela sua eficiência. No entanto, pensando na interação professor e aluno, ao notar que a maioria dos professores pesquisados $(48 \%)$ diz utilizar o fórum como recurso do Moodle para a postagem de atividades, em diferentes formatos, e tendo conhecimento que o fórum é mediado, na maioria das vezes, pelos tutores, pode-se notar que os professores estão replicando práticas docentes utilizadas em ambientes de ensino presencial e não usufruindo das potencialidades do AVA, no que tange às possibilidades de interação entre professores e alunos. Se bem utilizado, de acordo com 


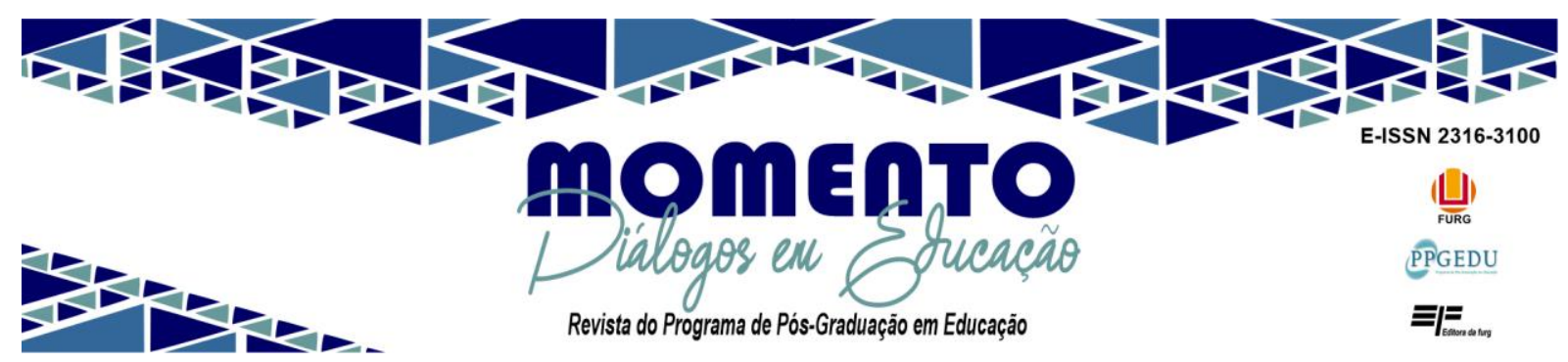

Paiva e Rodrigues Júnior (2004), o fórum pode permitir discussões públicas, interações escritas entre os atores da $\mathrm{EaD}$, com circulação de mensagens dos participantes de forma autônoma ou com monitoramento de um moderador, podendo ser este o tutor ou o professor. Isso mostra que os professores participantes deste estudo não estão engajados em práticas que possibilitem a troca e a co-construção dos conhecimentos, como um princípio pedagógico. Essas práticas podem ser transformadoras e emancipadoras, em relação à formação desses alunos.

Com referência ao tipo de material didático mais utilizado durante o curso técnico que ministram, $56 \%$ dos professores apontaram que usam as apostilas, $16 \%$ vídeos e livros e $12 \%$ periódicos e manuais. O restante dos professores pesquisados declarou que utiliza trechos ou capítulos de livros e resumos, páginas da web, DVD e CD (Gráfico 6).

GRÁFICO 6 - Material didático mais utilizado pelos docentes no Moodle

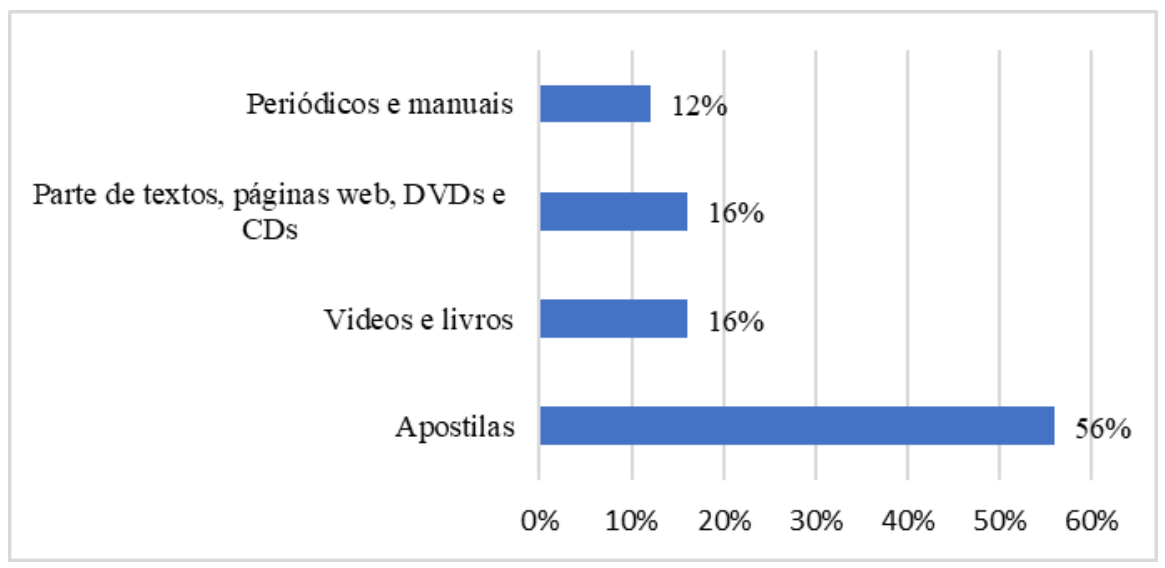

Fonte: Elaborado pelos autores

Nota-se que ainda é uma minoria que utiliza recursos digitais, embora a plataforma Moodle ofereça inúmeros recursos que possibilitam trabalhos compartilhados. Conforme Lévy (2000), mesmo com uma preparação dos docentes para a utilização de recursos didáticos, como apostilas, livros, há que se falar em utilização de multimídias e outras ferramentas digitais, como materiais didático-pedagógicos.

Como a plataforma Moodle favorece a elaboração de trabalhos colaborativos e 


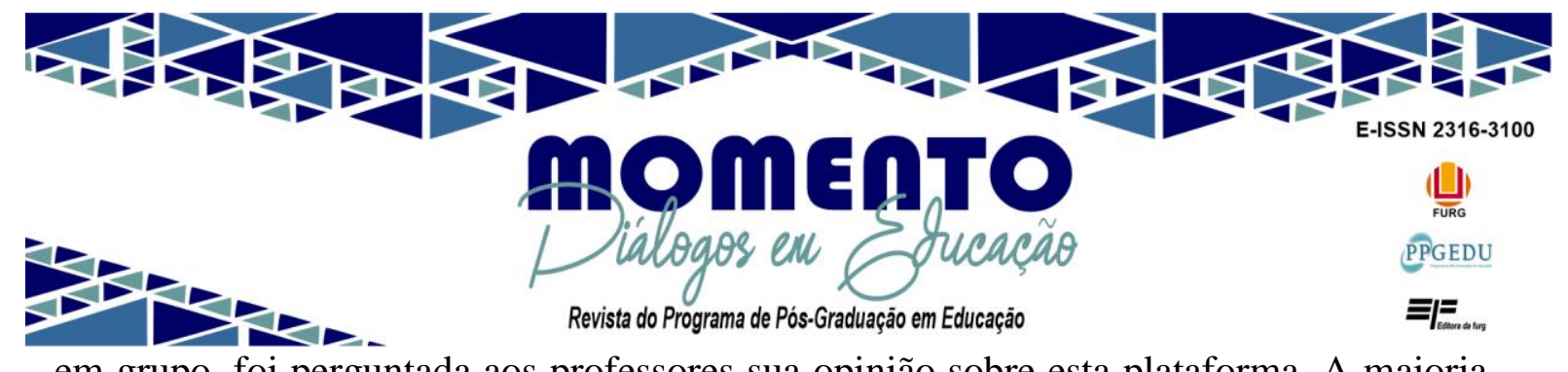

em grupo, foi perguntada aos professores sua opinião sobre esta plataforma. A maioria (64\%) respondeu que, às vezes, a plataforma favorece essas ações, não percebendo o Moodle como um ambiente que permite o compartilhamento de informações e conhecimento em trabalhos em grupo. Valentini e Soares (2010) evidenciam que os ambientes virtuais reproduzem a sala de aula presencial e física para o meio on-line, de modo a propiciar um suporte à colaboração, à aprendizagem fundamentada na pesquisa e ao compartilhamento e reutilização dos recursos disponíveis nessa plataforma.

Quando questionados sobre o fato da plataforma Moodle permitir ao professor criar ambientes de aprendizagem ricos e flexíveis, 64\% dos professores responderam que sempre permite. Essa possibilidade vem ao encontro do que defende o Ministério da Educação, quando expõe que as mídias utilizadas nos programas de EaD têm possibilidade de uso combinado de recursos, de forma a criar ambientes de aprendizagem que facilitem a interação e incentivem a comunicação. (BRASIL, 2007).

Em relação aos recursos adotados pelos professores pesquisados para uso na plataforma Moodle, nos cursos técnicos que ministram na $\mathrm{EaD}, 84 \%$ responderam que são "adequados", e o restante, "parcialmente adequados", em relação à aprendizagem almejada. Para Lévy (2000), os recursos tecnológicos na educação são importantes, pois propiciam que o conhecimento seja mais facilmente apreendido e retido, por provocar um envolvimento mais ativo do aluno, no processo de aprendizagem.

Quando questionados se consideram que o Moodle, como um ambiente virtual de aprendizagem, favorece a interação entre professor e aluno, a maioria (64\%) dos professores pesquisados declarou que sempre favorece. Esse resultado reflete a importância da discussão acerca da interação entre professor e aluno, na EaD. Segundo Faria e Salvadori (2010), essa interação relaciona as pessoas envolvidas no processo de ensino e de aprendizagem. O processo de aprendizagem é composto por aquele que aprende, aquele que ensina e as interações entre ambos.

Os ambientes virtuais de aprendizagem são espaços de relações sociais e cognitivo-sociais, que objetivam a construção do conhecimento, alimentados pelas interações entre os atores e mediados por recursos tecnológicos (VALENTINI; SOARES, 2010). Em relação às ferramentas adequadas para promover maior interação, $35 \%$ dos professores consideraram os chats; $17 \%$ as videoconferências e vídeo aulas; 


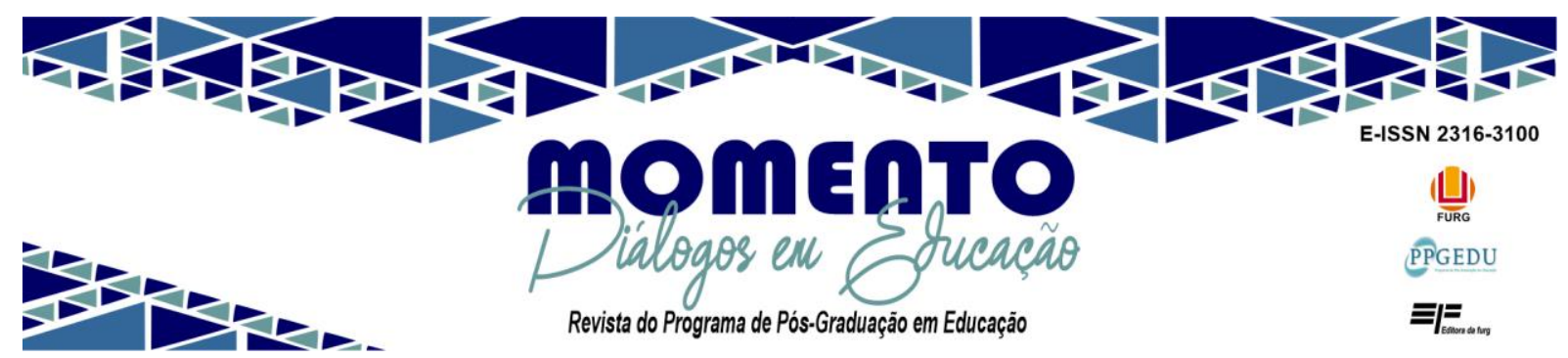

$27 \%$ evidenciaram e-mails e $18 \%$ arquivos postados em textos e $3 \%$ marcaram arquivos postados em apresentações (Gráfico 7).

GRÁFICO 7 - Ferramentas adequadas para promover maior interação

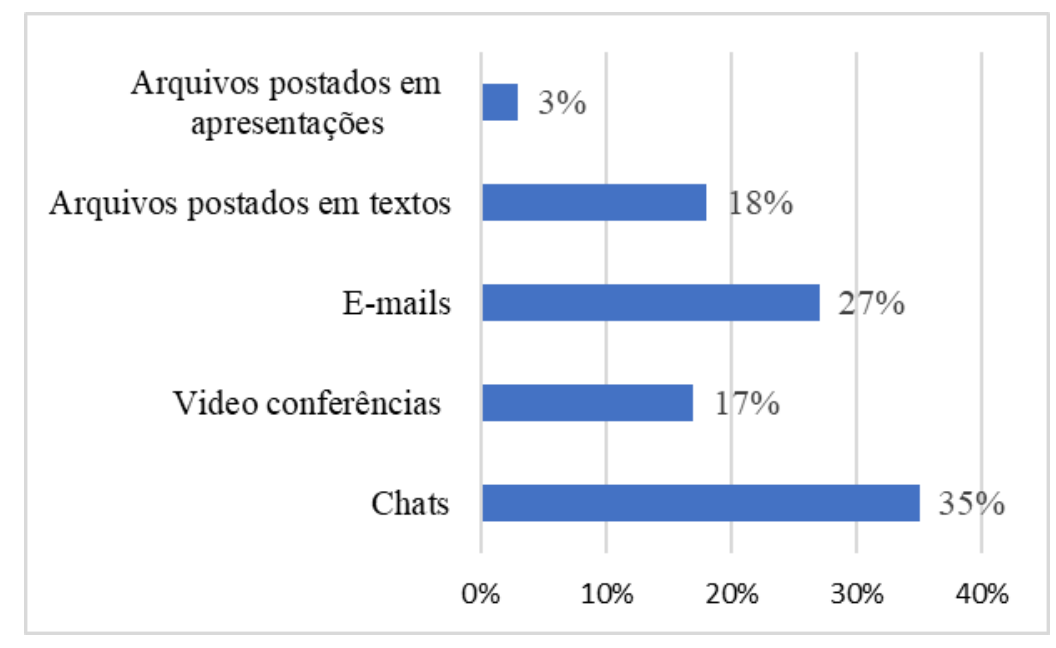

Fonte: Elaborado pelos autores

Esses resultados mostram que, grande parte (52\%) dos docentes, acredita que o chat e as videoconferências, que possibilitam comunicação síncrona, oferecem melhores resultados quando se trata de interação entre alunos e professores no AVA, o que vai ao encontro do que Valentini e Soares (2010) evidenciam sobre esses espaços virtuais. Para esses autores, esses ambientes propiciam desenvolvimento de condições, estratégias e intervenções de aprendizagem, organizadas de forma a motivar, além da construção de conceitos, a interação entre alunos, professores e objetos de conhecimento. (VALENTINI; SOARES, 2010).

Com relação à existência de uma frequência de troca de mensagens entre os professores e seus alunos através do Moodle, 60\% dos pesquisados responderam que sempre ocorre essa troca. Essas estratégias são evidenciadas por Palloff et al. (2002), para quem os professores podem, em seus cursos $\mathrm{EaD}$, incentivar a manter contato em redes sociais, promover encontros presenciais, elaborar trabalhos em grupos, com simulações ou projetos, motivando o trabalho em equipe.

Em relação às ferramentas de comunicação utilizadas com maior frequência 


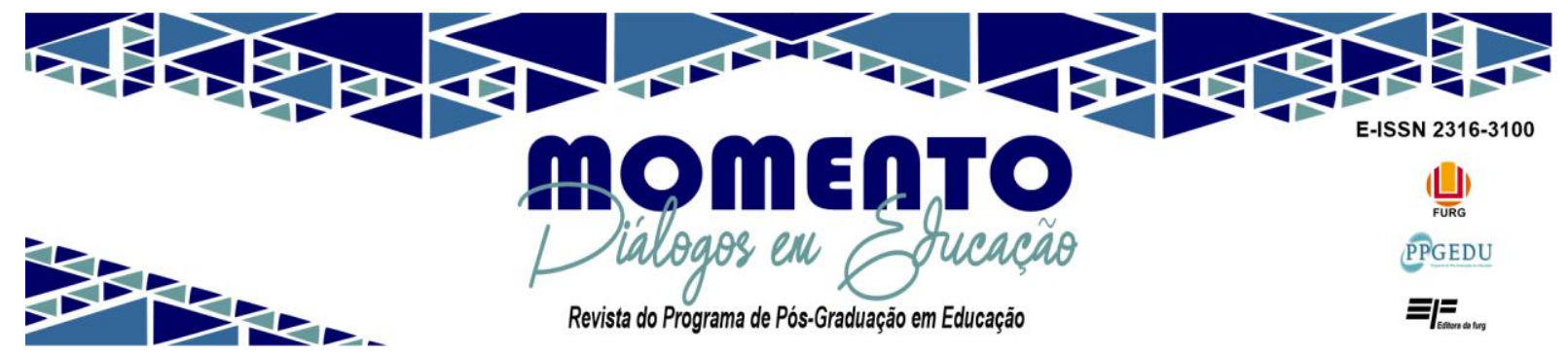

pelos professores, nos cursos técnicos $\mathrm{EaD}$, para interagir com seus alunos, os fóruns de discussão foram os mais apontados pelos professores pesquisados (56\%), seguidos pela internet e outras ferramentas do Moodle. A relevância da internet na EaD é notória, no entanto, as atividades oferecidas por meio da internet dependem da ferramenta utilizada, pois a internet em si viabiliza a comunicação por diferentes meios, como o email, o fórum, a rede social etc., meios esses que possibilitam realização de atividades muito diversificadas. Para Garcia Coelho e Tedesco (2017), vão desde aquelas sem qualquer interação entre os alunos, até aquelas com interação constante, há as atividades que são assíncronas, em que os alunos acessam quando desejarem, e aquelas atividades síncronas, que exigem a participação dos alunos, em um mesmo ambiente, e ao mesmo tempo.

No que tange às vantagens possibilitadas pela ferramenta fórum, quando explorada pelos professores, Garcia (2013) evidencia que, além de propiciar um tipo de comunicação entre os participantes sobre um tema específico, pode o docente propor um estudo de caso, possibilitar ao aluno que participe na resolução de um problema e, consequentemente, na construção do conhecimento de forma coletiva. Além disso, pode permitir aos participantes momentos de reflexão, estruturação do pensamento e desenvolver a argumentação de forma mais elaborada, o que contribui para a autonomia e uma comunicação de qualidade, de acordo com Martins e Meirinhos (2011).

Segundo Paiva e Rodrigues Júnior (2004), o fórum é um recurso virtual disponível, que propicia as interações entre alunos, tutores e professores, permitindo a comunicação síncrona, de forma interativa e dinâmica. No entanto, na maioria das vezes, o papel de mediador das discussões, utilizando o fórum em $\mathrm{EaD}$, é relegado aos tutores. Em um estudo sobre o papel do tutor na EaD, Villela (2018) mostrou que 83\% dos tutores participantes responderam que a interação com os alunos na $\mathrm{EaD}$, por meio do fórum, é realizada pelos tutores, o que permite inferir que a utilização do fórum em um curso $\mathrm{EaD}$ não é sinônimo de interação do professor com os alunos, como poderia ser.

Ainda em relação à interação com os alunos, $60 \%$ dos professores pesquisados responderam que a interação é sempre articulada. Para Palloff et al. (2002), na EaD o professor deve facilitar e abrir espaço aos aspectos pessoais e sociais do discente que estuda on-line. Esses autores defendem essa interação como uma forma de estimular as 


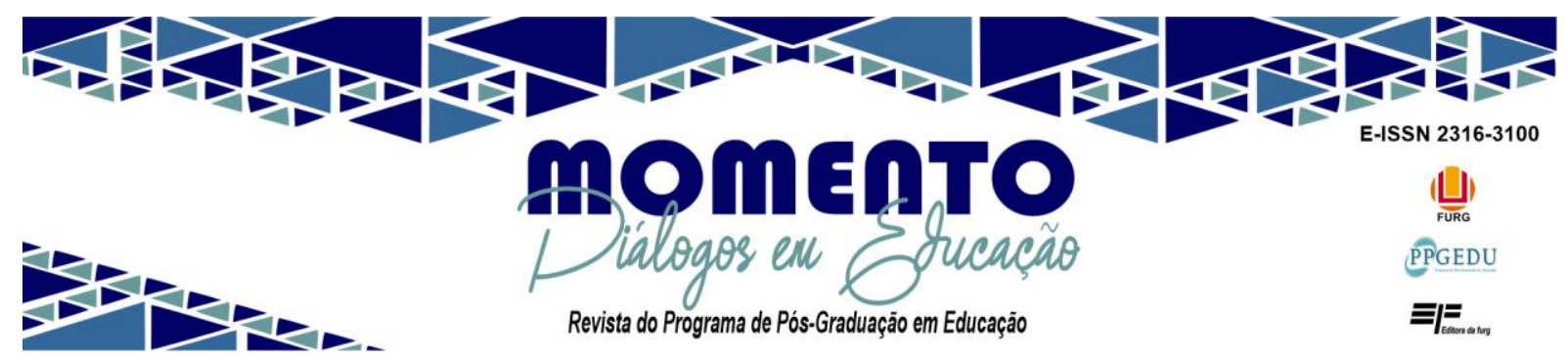

relações humanas e ajudar na afirmação, trabalhar no reconhecimento da contribuição do aluno e unir o grupo. A interação promove a colaboração mútua entre os participantes e torna possível o desenvolvimento do pensamento conjunto, o que pode ser considerado a essência dos princípios de se construir e manter uma comunidade virtual.

Em relação à utilização das redes sociais e outros meios externos à plataforma Moodle para promover a interação entre professor e aluno, 56\% dos professores responderam que "às vezes" são utilizados; 20\%, que sempre são utilizados; $20 \%$, que nunca utilizaram redes sociais para este objetivo, e 4\% não responderam. As análises sugerem que ainda não é uma maioria dos professores que utiliza esse recurso como meio de promover a interação com seus alunos. Para Valentini e Soares (2010), as interações entre os atores da $\mathrm{EaD}$ devem ser realizadas em um espaço de relações sociais, com foco no conhecimento, no ensino e na aprendizagem, mediados por recursos de hipermídia. De acordo com as autoras, o foco principal não se encontra apenas na forma que essa interação ocorre (através de internet e de outros recursos), mas, sim, com ênfase no resultado alcançado por meio desses recursos.

Outro modo de interação entre os atores do processo de ensino e aprendizagem na $\mathrm{EaD}$ se dá nos encontros presenciais. Nesses momentos, adentram novos elementos na aprendizagem que era somente virtual, o que impacta na qualidade da aprendizagem. 92\% dos professores pesquisados evidenciaram que participam e mediam esses encontros, 8\% responderam que "às vezes" participam. No caso de ausência dos professores, apontaram que há a participação dos tutores nesses encontros. Entretanto, de acordo com Palloff et al. (2002), é necessário que os docentes estejam conscientes do impacto que a EaD tem na aprendizagem e as mudanças de paradigma necessárias ao aluno que opta por esta modalidade de ensino, não devendo este delegar suas funções aos tutores.

A interação propiciada aos alunos, em outros tipos de atividades na $\mathrm{EaD}$, foi abordada na questão sobre o apoio da Instituição em relação à participação dos discentes em eventos de caráter científico (congressos, encontros, seminários, etc.). $56 \%$ dos docentes apontaram que esse apoio é "razoavelmente adequado", 36\% 


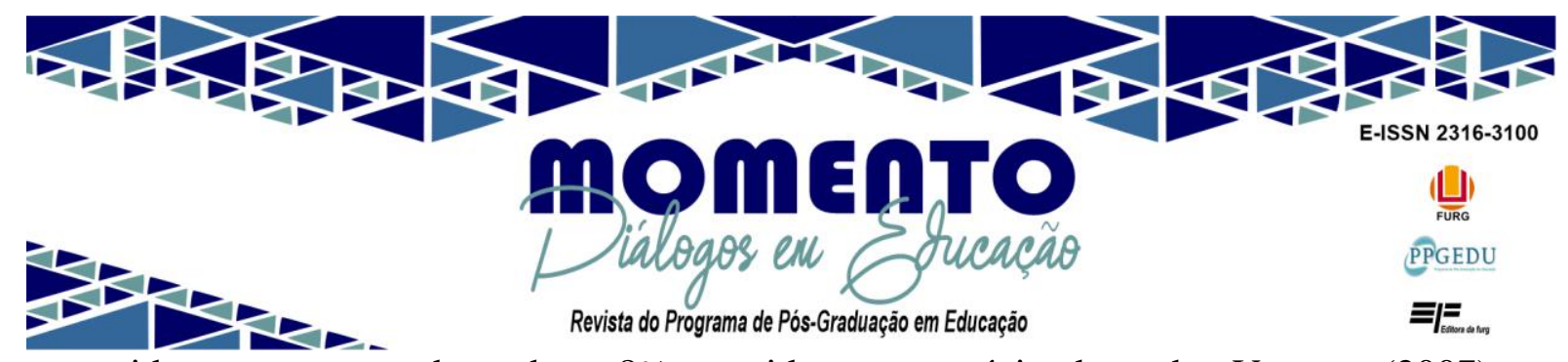

consideraram como adequado e $8 \%$ consideram que é inadequado. Vergara (2007) evidencia a necessidade da participação dos alunos em atividades que dependem de interação em eventos que se formalizam os processos das relações de diversidade. Para Moran (2007), o processo de ensino e de aprendizagem não se limita ao trabalho dentro da escola, mas exige uma transformação do que se faz, no interior da sala de aula e, também, fora dela, seja em um ambiente presencial ou virtual.

\section{CONSIDERAÇÕES FINAIS}

Durante séculos, estabeleceu-se uma visualização e associação da escola a um conjunto de salas de aula, com alunos sentados nas carteiras enfileiradas e o professor no quadro à frente, como o detentor dos saberes. Atualmente, esse cenário mudou com as novas tendências das modalidades de ensino, para as quais o professor deve se reinventar e aprimorar conhecimentos a cada dia, frente à integração das TDIC na modalidade de ensino à distância, um ensino baseado em plataformas virtuais, conectadas pela rede mundial de computadores.

O estudo das concepções dos docentes está estritamente ligado ao de suas crenças, conforme defende Ponte (1992). Remetendo ao objetivo desta pesquisa, buscou-se investigar as concepções dos professores em relação à interação entre professor e aluno, no âmbito dos cursos técnicos $\mathrm{EaD}$, ofertados por uma instituição pública de ensino do Sul de Minas Gerais. Para Freire (2014), perceber a importância da conscientização das próprias concepções dos professores é essencial no processo educativo.

A média de idade dos professores participantes deste estudo, 36 anos, mostra que os docentes que trabalham com a $\mathrm{EaD}$ na instituição pesquisada constituem um grupo relativamente jovem, o que se pressupõe uma geração mais antenada com as tecnologias digitais (uma interface entre os nativos e os imigrantes digitais). Também é recente o ingresso desses profissionais nessa instituição, com máximo de cinco anos. Desses profissionais, $50 \%$ teve contato com a $\mathrm{EaD}$ na formação, porém, um dado a ser discutido é que a maioria não teve componentes curriculares que os preparasse para trabalhar com EaD e nem com as TDIC, durante a graduação ou pós-graduação cursada. 


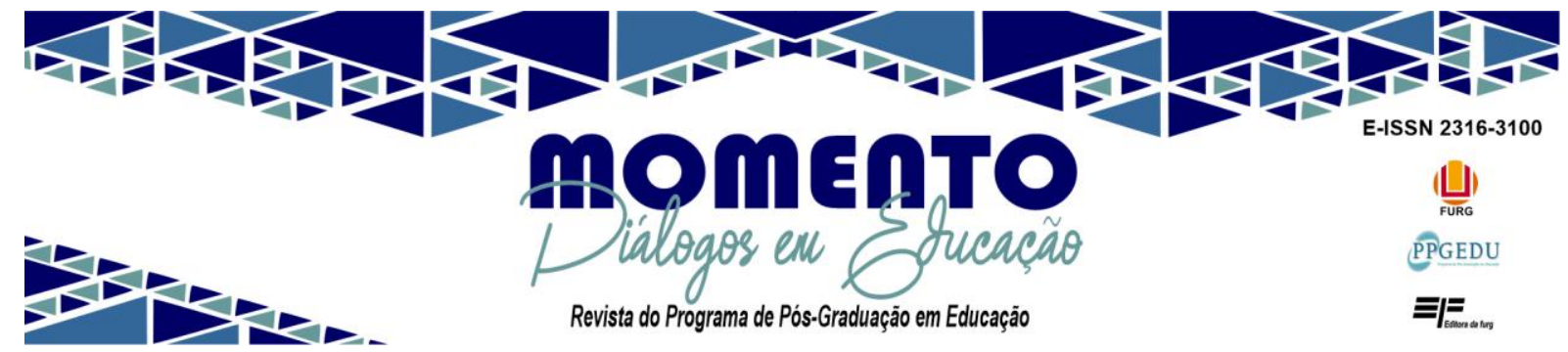

E, ainda, apenas uma minoria declarou possuir experiência com a $\mathrm{EaD}$, durante a realização de tais cursos, o que demanda atualização por meio de cursos que os subsidiem na atuação docente, nessa modalidade de ensino.

Neste estudo, ficou explícita a exigência de novos papéis para o professor que atua na EaD. A priori, esse profissional deve ser capacitado, comportamental e tecnicamente, para que possa utilizar e incentivar o uso efetivo, eficiente e contínuo das TDIC. Além disso, deve estar preparado para a seleção e utilização das ferramentas disponibilizadas nos AVA, de forma coerente, consciente, responsável e eficaz, para que esses recursos possam proporcionar aos alunos uma aprendizagem adequada e uma interação entre eles, principais personagens desse processo, foco e objetivo primordial não apenas da $\mathrm{EaD}$, mas da educação como um todo. De acordo com Ponte, Matos e Abrantes (1999), as ações dos professores resultam da combinação de experimentações e ambições, que vão se transformando em hábitos que os identificam.

Ao utilizar os recursos das TDIC nas atividades pedagógicas em AVA, o docente precisa ter um domínio, que envolve os conceitos disciplinares, e ainda das tecnologias, para interagir com seus alunos e orientá-los no processo de ensino e de aprendizagem, como evidencia Valente (2014). Além disso, as ações dos professores da $\mathrm{EaD}$ devem ser redefinidas, para que possam atuar como mediadores das aprendizagens, compreendendo o papel das TDIC no processo de construção do conhecimento e como o aluno está aprendendo. Para tanto, o professor deverá ser um incansável pesquisador, que se reinventa a cada dia, acatando os desafios e a imprevisibilidade da atualidade, aprimorando-se, cada vez mais, conforme defende Kenski (2003).

Quanto à plataforma Moodle, compreende-se que grande parte dos professores pesquisados reconheceram que não possuem o conhecimento necessário para seu uso de forma segura, embora a maioria tenha recomendado e reconhecido a qualidade dessa plataforma. Para Ponte, Matos e Abrantes (1999), as concepções docentes abarcam mais do que o domínio do conhecimento acerca dos conteúdos e competências pedagógicas, são influenciadas pela sua formação cultural e social.

A maioria dos docentes declara que a plataforma Moodle favorece a elaboração 


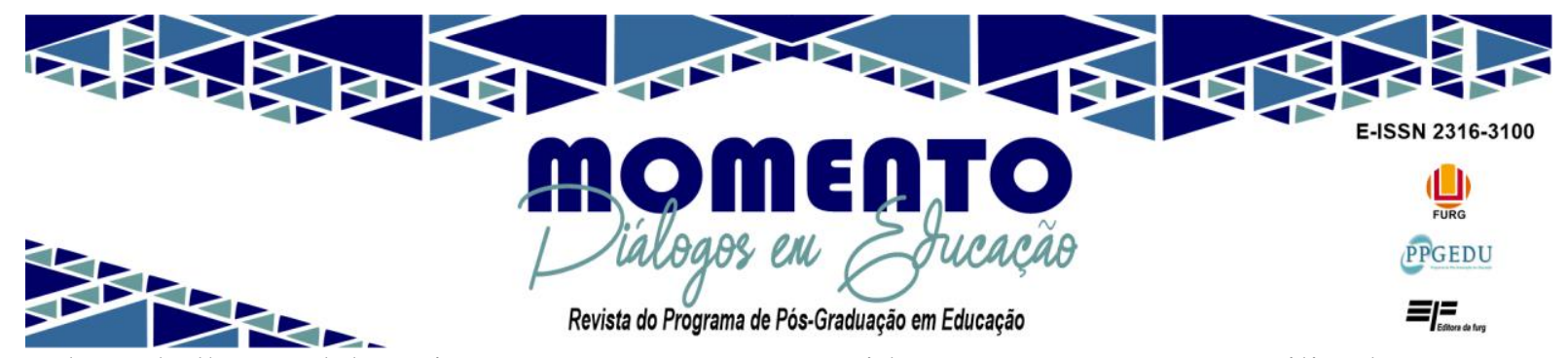

de trabalhos colaborativos e em grupo, e considera que os recursos utilizados são adequados no processo de ensino e aprendizagem na EaD. No entanto, os resultados mostram que não conhecem os recursos disponíveis nesse AVA, o que ficou claro quando explicitaram que os recursos mais utilizados por eles são os fóruns e as apostilas escritas, mesmo assinalando que o Moodle permite a criação de ambientes ricos e flexíveis.

O professor possui dificuldades em relação às mudanças de paradigma, lembra Veiga Neto (2002). Nesse estudo se observou que os docentes pesquisados utilizam, de forma efetiva, textos e apostilas em formato "pdf", postados no Moodle, considerandoos um recurso adequado. Com base neste dado, a resistência à inovação de metodologias de ensino fica clara, visto que essa plataforma dispõe de vários outros recursos mais interativos do que apenas textos, que podem não ser bem recebidos pelos alunos. Para Freire (2014) as escolhas do docente dependem de suas concepções.

Em relação à disponibilidade dos docentes para o atendimento aos alunos nos cursos técnicos em EaD, alegaram haver troca de mensagens com seus alunos e ainda que a comunicação entre eles é bem articulada através da plataforma Moodle e, mesmo, por meio de outras ferramentas extra plataforma, como as redes sociais, por exemplo. No entanto, o que se percebe nas análises dos dados é que a maioria cita apenas o chat, mais comumente utilizado para interação entre aluno e aluno, e o fórum como recurso de interação, todavia, com a mediação de tutores, ou seja, esses meios são pouco utilizados pelos professores. Essa ausência do uso das ferramentas dessa plataforma que permitem a interação professor e aluno pode ser justificada pelo fato de ser difícil para os professores mudarem suas concepções. De acordo com Ponte (1992), as concepções possuem caráter cognitivo e agem semelhante a um filtro, como um bloqueador para novas situações.

No que tange à atuação dos tutores, a maioria dos professores pesquisados considerou adequada, porém, ao mesmo tempo, avaliaram que os tutores nem sempre dominam adequadamente os conteúdos e das ferramentas do Moodle, o que parece uma contradição. De acordo com Becker (2012), o docente, mesmo que inconscientemente, acredita no mito da transferência do conhecimento, nesse caso, para o tutor. Segundo os professores entrevistados, na ausência deles, nos encontros presenciais, há a 


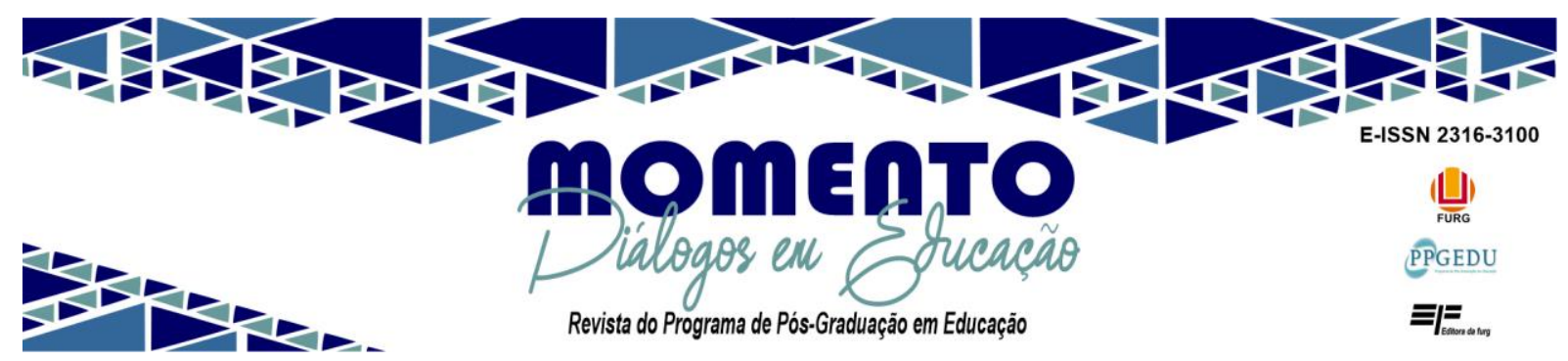

participação dos tutores. Para Maia (2002), o tutor está mais próximo ao aluno do que o professor $\mathrm{EaD}$, o qual se dedica mais ao desenvolvimento do conteúdo a ser ministrado e a estruturação do material e das atividades a serem utilizadas nas aulas.

Sobre os instrumentos de avaliação na plataforma Moodle, os docentes declararam usar predominantemente testes online com correção automática, e ainda exercícios postados em formato de texto e os fóruns. Percebe-se o uso em grande escala de ferramentas automatizadas para "gerir e medir" o conhecimento do aluno. Ainda se observa que as atividades de pesquisa e extensão realizadas pelos alunos da EaD da referida instituição não são conhecidas pela maioria dos professores, e que o apoio dessa instituição à participação dos estudantes em eventos de caráter científico também é inadequado. Conforme Pozo (2016), é necessário que o docente faça uma reflexão sobre os resultados de sua atuação pedagógica, para que se obtenha sucesso nos processos de ensino e de aprendizagem.

No que tange à interação entre professor e aluno, os resultados deste estudo mostraram que os professores consideraram que essa interação existe, mas a interseção desses resultados revela que essa interação pode ser considerada ainda incipiente, o que pode ter diferentes justificativas. Percebe-se que há grande interatividade entre aluno e plataforma, entre professor e plataforma e entre tutor e plataforma, porém, ao serem analisados os recursos utilizados no Moodle pelos professores, nota-se que eles ainda não se utilizam de todas as ferramentas disponíveis que podem promover a interação entre professor e aluno. Assim, nota-se que, embora haja os recursos tecnológicos, não ocorre a interação entre professores e alunos com a troca de ações e informações de forma síncrona no ambiente Moodle. São resultados que vão na contramão de uma construção colaborativa do conhecimento, em ambientes virtuais, importantes para a aprendizagem dos alunos, como lembram Garcia Coelho e Tedesco (2017) e Onrubia, Colomina e Engel (2010).

Outra justificativa para essa baixa interação, verificada nos resultados deste estudo, é que, muitas vezes, o papel do professor passa a ser desempenhado pela figura do tutor, comumente presente nos cursos de $\mathrm{EaD}$, auxiliando os alunos no acesso ao AVA, apoiando-os na realização das atividades, no esclarecimento de dúvidas e na 


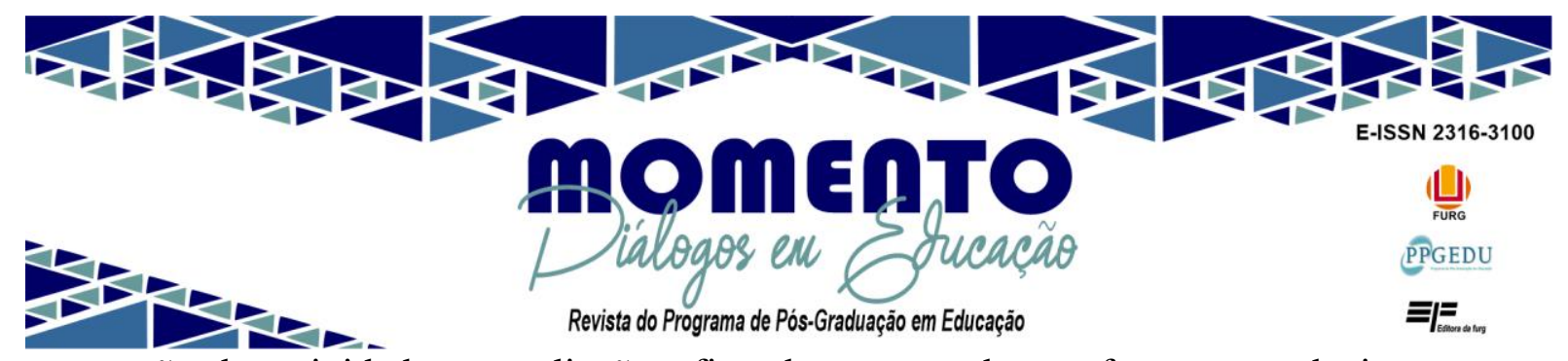

correção das atividades e avaliações, ficando a cargo dos professores produzirem os materiais didáticos. Conforme Garnica e Fernandes (2002), as concepções e práticas educativas se retroalimentam. Nessa direção, Ponte (1992) afirma que as concepções dos professores emergem nas interações interindividuais com evolução dependente das dinâmicas coletivas. A infiltração de elementos sociais na construção do saber reafirma a perspectiva da existência da interação entre as concepções e as práticas educativas que, por sua vez, são influenciadas pelas concepções e fundamentam os caminhos seguidos pelos professores.

Em suma, a EaD encontra-se em ascensão e revela-se uma modalidade de ensino que exige dos professores habilidades e competências para a utilização efetiva das ferramentas e dos recursos tecnológicos digitais, presentes nos AVA, os quais contribuem para a interação entre os principais atores do processo educacional, alunos e professores, dentro e fora desses ambientes. Dessa forma, essa modalidade de ensino pode superar o mito de uma educação "distante", para ser uma educação eficiente, que propicie aos alunos uma formação para o exercício da cidadania.

\section{Referências}

ALMEIDA, Maria Elizabete Bianconcini de et al. O currículo na cultura digital e a integração currículo e tecnologias. In: CERNY, R. Z. et al. (Org.). Formaçãa de Educadores na Cultura Digital. Florianópolis: UFSC/CED/NUP, 2017. p. 381-410. Disponível em: http://nup.ced.ufsc.br/files/2017/06/PDF_Formacao_de_Educadores_na_Cultura_Digita 1_a_construcao_coletiva_de_uma-proposta3.pdf. Acesso em: 27 jun. 2017.

BECKER, Fernando. A epistemologia do professor: o cotidiano da escola. 15. ed. Rio de Janeiro: Vozes, 2012.

BOROKHOVSKI, Eugene et al. Are contextual and designed student-student interaction treatments equally effective in distance education? Distance Education, v. 33, n. 3, p. 311-329, 2012.

BRAGA, Denise Bértoli; VÓVIO, Claudia Lemos. Uso de tecnologia e participação em letramentos digitais em contextos de desigualdade. In: BRAGA, Denise Bértoli (Org.).

Tecnologias digitais da informação e comunicação e participação social. São Paulo: Cortez Editora, 2015. p. 33-67.

BRASIL. Ministério da Educação. Cursos técnicos facilitam o acesso ao mercado de trabalho: as qualificações oferecidas no Brasil são referência para outros países.

Brasília, DF: Ministério da Educação, 2015. Disponível em: 


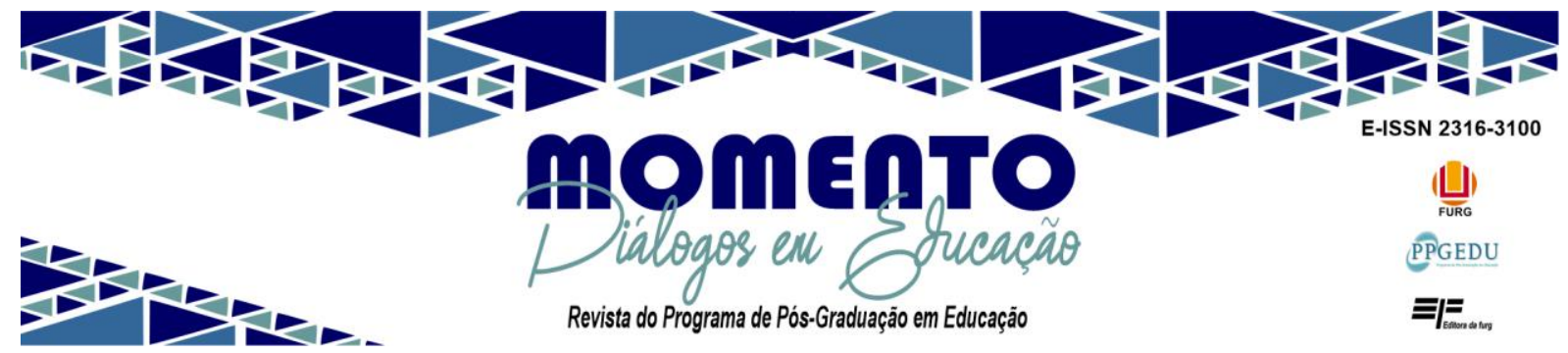

http://www.brasil.gov.br/noticias/educacao-e-ciencia/2009/11/cursos-tecnicosfacilitam-o-acesso-ao-mercado-de-trabalho. Acesso em: 12 abr. 2019.

BRASIL. Ministério da Educação. Secretaria de Educação a Distância. Referências de qualidade para educação superior a distância. Brasília, DF: Ministério da Educação/ Secretaria de Educação a Distância, 2007. 31 p. Disponível:

http://portal.mec.gov.br/seed/arquivos/pdf/legislacao/refead1.pdf. Acesso em: 21 mar. 2019.

FARIA, Adriano Antonio; SALVADORI, Angela. A educação a distância e seu movimento histórico no Brasil. Revista das Faculdades Santa Cruz, v. 8, n. 1, p. 1522, 2010. Disponível em: http://docplayer.com.br/4349056-A-educacao-a-distancia-eseu-movimento-historico-no-brasil.html. Acesso em: 1 mar. 2019.

FERREIRA, Andréia de Assis; VENTURA, Paulo Cezar Santos. Concepções de ensino de história: um estudo sobre a rede municipal de ensino de belo horizonte. Cadernos de História, Uberlândia, v. 15, n. 1, p. 109-124, 2007. Disponível em:

http://www.academia.edu/945092/Concep\%C3\%A7\%C3\%B5es_de_ensino_de_hist\%C 3\%B3ria_um_estudo_sobre_a_rede_municipal_de_ensino_de_Belo_Horizonte. Acesso em: 5 mar. 2019.

FREIRE, Paulo. Extensão ou comunicação?. Rio de Janeiro: Editora Paz e Terra, 2014.

GARCIA COELHO, Willyans; TEDESCO, Patrícia Cabral de Azevedo Restelli. A percepção do outro no ambiente virtual de aprendizagem: presença social e suas implicações para Educação a Distância. Revista Brasileira de Educação, Rio de Janeiro, v. 22, n. 70, p. 609-624, 2017. Disponível em:

http://www.scielo.br/pdf/rbedu/v22n70/1809-449X-rbedu-22-70-00609.pdf. Acesso em: 18 fev. 2019.

GARCIA, Marta Fernandes et al. Novas competências docentes frente às tecnologias digitais interativas. Teoria e Prática da Educação, Maringá, v. 14, n. 1, p. 79-87, 2011. Disponível em:

http://periodicos.uem.br/ojs/index.php/TeorPratEduc/article/view/16108/8715. Acesso em: 11 mar. 2019.

GARCIA, Rosineide Pereira Mubarack. Avaliação da aprendizagem na educação a distância na perspectiva comunicacional. Cruz das Almas: UFRB, 2013. 180 p.

GARNICA, Antonio Vicente Marafioti. Um ensaio sobre as concepções de professores de Matemática: possibilidades metodológicas e um exercício de pesquisa. Educação e Pesquisa, São Paulo, v. 34, n. 3, p. 495-510, 2008. Disponível em: http://www.scielo.br/pdf/ep/v34n3/v34n3a06. Acesso em: 14 fev. 2019.

GARNICA, Antonio Vicente Marafioti; FERNANDES, Dea Nunes. Concepções de professores formadores de professores: exposição e análise de seu sentido doutrinário. Quadrante, Lisboa, v. 11, n. 2, p. 76-98, 2002. Disponível em: https://quadrante.apm.pt/index.php/quadrante/article/view/285/245. Acesso em: $27 \mathrm{fev}$. 2019. 


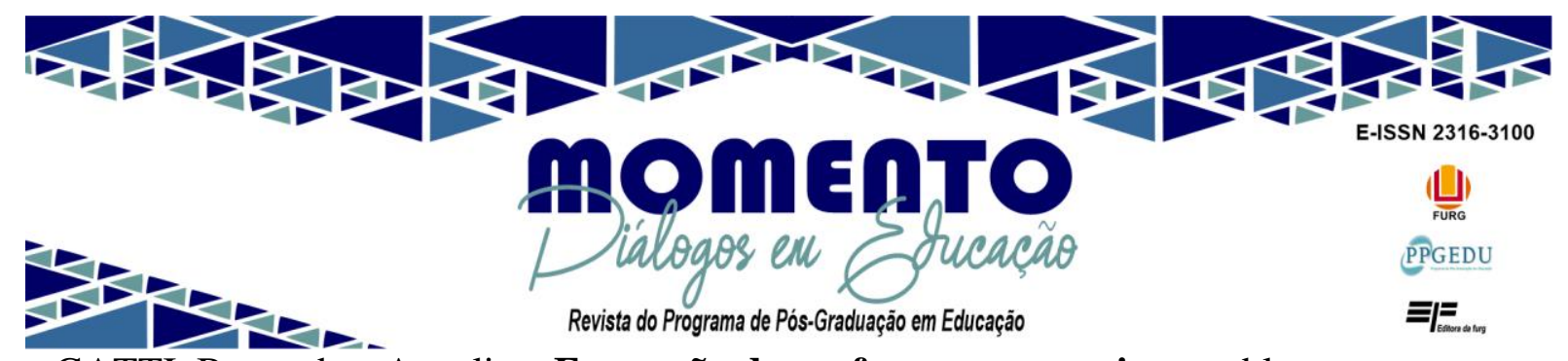

GATTI, Bernardete Angelina. Formação de professores e carreira: problemas e movimentos de renovação. São Paulo: Autores Associados, 2000.

KENSKI, Vani Moreira. A urgência de propostas inovadoras para a formação de professores para todos os níveis de ensino. Revista Diálogo Educacional, Curitiba, v. 15, n. 45, p. 423-441, 2015. Disponível em: https://periodicos.pucpr.br/index.php/dialogoeducacional/article/view/1963/1864. Acesso em: 3 fev. 2019.

KENSKI, Vani Moreira. Tecnologias e ensino presencial e a distância. Campinas: Papirus Editora, 2003.

LAPA, Andrea Brandão; BELLONI, Maria Luiza. Educação a distância como mídiaeducação. Perspectiva, Florianópolis, v. 30, n. 1, p. 175-196, 2012. Disponível em: https://periodicos.ufsc.br/index.php/perspectiva/article/view/2175795X.2012v30n1p175/21919. Acesso em: 10 fev. 2019.

LÉVY, Pierre. As tecnologias da inteligência: o futuro do pensamento na era da informática. Tradução: Carlos Irineu da Costa. Rio de Janeiro: Editora 34, 2000. (Coleção TRANS).

MAIA, Carmem. Guia brasileiro de educação a distância: 2000/2001. São Paulo: Editora Esfera, 2002.

MARTINS, Maria Antónia; MEIRINHOS, Manuel. Análise das relações entre intervenientes num fórum de discussão em contexto de aprendizagem. In: CONFERÊNCIA IBÉRICA - INOVAÇÃO NA EDUCAÇÃO COM TIC, 2011, Bragança. Anais [...]. Bragança: Instituto Politécnico de Bragança, 2011. p. 145-162. Disponível em: http://hdl.handle.net/10198/6180. Acesso em: 21 ago. 2015.

MORAN, José Manuel. A educação que desejamos: novos desafios e como chegar lá. Campinas: Papirus Editora, 2007.

NASCIMENTO, Francisco Elionardo de Melo; SILVA, Denilson Gomes. Educação mediada por tecnologia: inovações no processo de ensino e aprendizagem-uma revisão integrativa. Abakos, Belo Horizonte, v. 6, n. 2, p. 72-91, 2018. Disponível em: http://periodicos.pucminas.br/index.php/abakos/article/view/15550/13197. Acesso em: 7 fev. 2019.

NÓVOA, António. (Org.). Vidas de professores. Porto: Porto Editora, 2013.

ONRUBIA, Javier; COLOMINA, Rosa; ENGEL, Anna. As comunidades virtuais de aprendizagem baseadas no trabalho em grupo e na aprendizagem colaborativa. In: COLL, César; MONEREO, Carles. (Org.). Psicologia da educação virtual: aprender e ensinar com as tecnologias da informação e da comunicação. Porto Alegre: Artmed, 2010 .

PAIVA, Vera Lúcia Menezes de Oliveira e; RODRIGUES-JÚNIOR, Adail Sebastião. Fóruns on-line: intertextualidade e footing na construção do conhecimento. 2004. Disponível em: http://www.veramenezes.com/forum.pdf. Acesso em: 3 fev. 2019.

PALLOFF, Rena M. et al. Construindo comunidade de aprendizagem no 


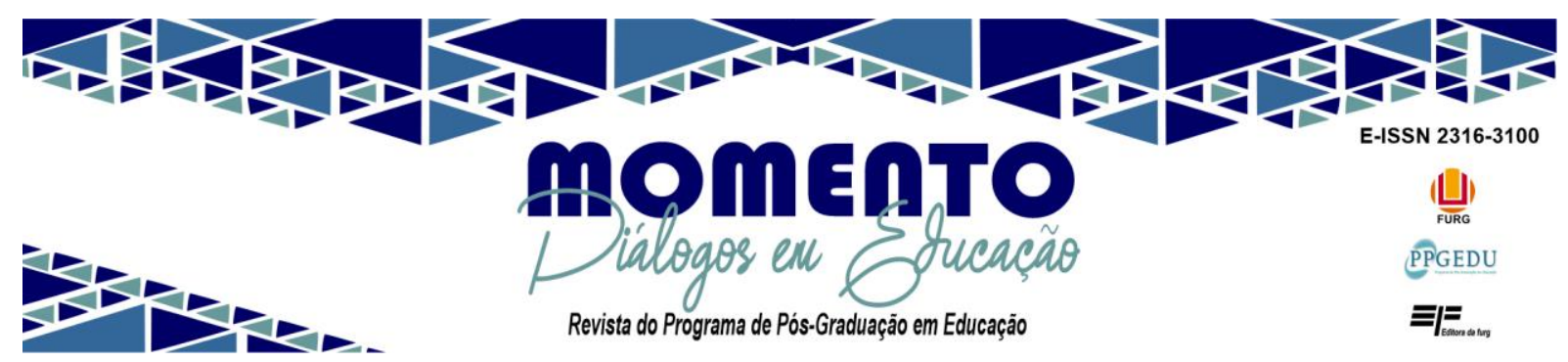

ciberespaço: estratégias eficientes para salas de aula on-line. Porto Alegre: Artmed, 2002.

PLACCO, Vera Maria Nigro de Souza; SILVA, Sylvia Helena Souza da. A formação do professor: reflexões, desafios, perspectivas. In: BRUNO, Eliane Bambini Gorgueira; ALMEIDA, Laurinda Ramalho de; CHRISTOV, Luiza Helena da Silva. Coordenador pedagógico e a formação docente. São Paulo: Edições Loyola, 2000. p. 25-32.

PONTE, João Pedro da. Concepções dos professores de matemática e processos de formação. In: PONTE, João Pedro da. Educação matemática: temas de investigação. Lisboa: Instituto de Inovação Educacional, 1992. p 185-239.

PONTE, João Pedro da; MATOS, José Manuel; ABRANTES, Paulo. Investigação em educação matemática: implicações curriculares. Lisboa: Instituto de Inovação Educacional, 1999. 356 p.

POZO, Juan Ignacio. Aprendizes e mestres: a nova cultura da aprendizagem. Porto Alegre: Artmed, 2016. 296 p.

PRADO, Maria Elizabete Brisola Brito; VALENTE, José Armando. A educação a distância possibilitando a formação do professor com base no ciclo da prática pedagógica. In: MORAES, Maria Cândida (Org.). Educação a distância: fundamentos e práticas. Campinas: Unicamp/Nied, 2002. p. 27-50.

SABBATINI, Renato Marcos Endrizzi. Ambiente de ensino e aprendizagem via internet: a plataforma moodle. Campinas: Instituto Edumed, 2007.

SOARES-LEITE, Werlayne Stuart; NASCIMENTO-RIBEIRO, Carlos Augusto do. A inclusão das TICs na educação brasileira: problemas e desafios. Revista Internacional de Investigación en Educación, v. 5, n. 10, p. 173-187, 2012. Disponível em: https://dialnet.unirioja.es/servlet/articulo?codigo=4434902. Acesso em: 19 fev. 2019.

SOUZA, Maria Carolina Santos de; BURNHAM, Teresinha Froés. Produção do conhecimento em EaD: um elo entre professor-curso-aluno. In: SALGADO, Maria Umbelina Caiafa. Tecnologias da Educação: ensinando e aprendendo com as TIC: guia do cursista. Brasília, DF: Ministério da Educação, 2008. p. 67-83. Disponível em: http://proinfo100h.profmarceloxt.com.br/menus/manuais/guia_cursista.pdf. Acesso em: 24 fev. 2019.

VALENTE, José Armando. Blended learning e as mudanças no ensino superior: a proposta da sala de aula invertida. Educar em Revista, Curitiba, n. 4, p. 79-97, 2014. Disponível em: https://www.scielo.br/pdf/er/nspe4/0101-4358-er-esp-04-00079.pdf. Acesso em: 2 fev. 2019.

VALENTE, José Armando. O ensino hibrido veio para ficar. In: BACICH, Lilian; NETO, Adolfo Tanzi; TREVISANI, Fernando de Mello. Ensino híbrido: personalização e tecnologia na educação. São Paulo: Penso Editora, 2015. p. 13-17.

VALENTINI, Carla Beatris; SOARES, Eliana Maria do Sacramento. Aprendizagem em ambientes virtuais: compartilhando ideias e construindo cenários. Caxias do Sul: Educs, 2010. Ebook. 331 p. Disponível em: 


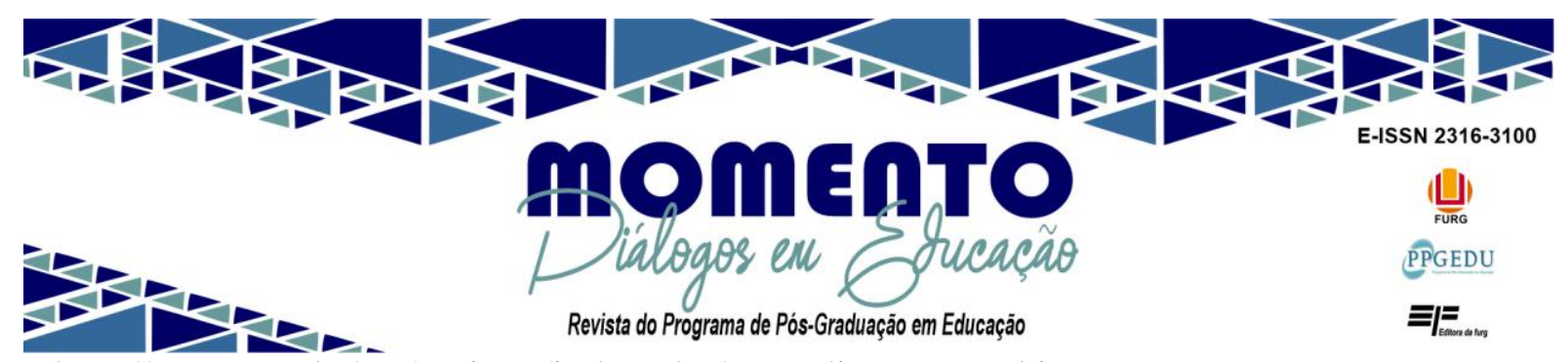

http://www.ucs.br/etc/revistas/index.php/aprendizagem-ambientes-

virtuais/article/view/393/323. Acesso em: 2 fev. 2019.

VEIGA-NETO, Alfredo. Espaço e currículo. In: LOPES, Alice Casimiro; MACEDO, Elizabeth (Org.). Disciplinas e integração curricular: história e políticas. Rio de Janeiro: DP\&A, 2002. p. 145-176.

VERGARA, Sylvia Constant. Estreitando relacionamentos na educação a distância. Cadernos EBAPE. Br, v. 5, p. 01-08, 2007. Disponível em:

http://www.scielo.br/pdf/cebape/v5nspe/v5nspea10.pdf. Acesso em: 24 fev. 2019.

VILLELA; Ana Paula. O papel do tutor na educação a distância. 2018. 124 f.

Dissertação (Mestrado em Educação) - Universidade do Vale do Sapucaí, Pouso Alegre, 2018. Disponível em: http://www.univas.edu.br/me/docs/dissertacoes2/146.pdf. Acesso em: 30 jun. 2019.

Submissão em: 03-06-2019

Aceito em: 05-07-2020 